\title{
Free Movement of Dual EU Citizens
}

\author{
David A.J.G. de Groot*
}

Nationality is a curious good. You either have it, or you don't; you can acquire it and you can lose it; you can have one or multiple. The problem for those with multiple nationalities is that only one at a time can be applied to each specific situation. The question then is, which nationality is applied to which specific situation?

In the book that was launched at the conference where this Chapter was first introduced, ${ }^{1}$ AG Szpunar and Blas López wrote that situations where the nationality of a person does not reflect the Member State of origin where this person was born and always resided, and situations of dual EU citizens "should be taken into account, firstly, by the EU legislator and, secondly, by the Court of Justice in its interpretation of EU law, to prevent Union citizenship becoming in part a victim of its own success". ${ }^{2}$ In many cases where nationality is a connecting factor for the establishment of rights, the Court only considers the implications of the judgment on dual EU citizens when they are a party to the case, but fails to do so when they are not a party. ${ }^{3}$ However, it is not only the EU

* Independent Consultant and PhD candidate, National Center of Competence in Research the Migration-Mobility Nexus (NCCR on the move) and University of Bern. This research was funded by the Swiss National Science Foundation.

1 Kochenov, D., ed. (2017). EU Citizenship and Federalism: The Role of Rights. Cambridge: Cambridge University Press. At the conference EU Citizenship, Federalism and Rights, Luxembourg, 18-19 November 2017.

2 Szpunar, M., and Blas López, M.E. (2017). Member State Nationality. In: Kochenov (ed.), EU Citizenship and Federalism, cit., pp. 122-123.

3 The Court of Justice did consider it in Bogendorff von Wolffersdorff and in Freitag, where the applicants were dual EU citizens. However, for example in Runevič-Vardyn the fact that there was a dual EU citizen child of the applicants was mentioned and that he was born after the case was submitted and therefore couldn't be an applicant, but for the effects of the judgment it seemed to be not considered. Nor did the Court even consider what would happen if Sayn-Wittgenstein had also had the German nationality next to the Austrian one. Such a situation would have led to a clash of constitutions. Court of Justice: judgment of 2 June 2016, case C-438/14, Bogendorff von Wolffersdorff; judgment of 8 June 2017, case C-541/15, Freitag; 
legislator and the Court, but also academia that should take more account of the free movement rights of dual EU citizens. There is extensive literature that touches upon the subject of dual nationality in general. This mostly relates to topics of whether it should be allowed or not; ${ }^{4}$ private international law; ${ }^{5}$ loyalty issues; ${ }^{6}$ political participation; ${ }^{7}$ whether or not one should renounce the other Member State's nationality upon naturalisation in another Member

judgment of 12 May 2011, case C-391/o9, Runevič-Vardyn; judgment of 22 December 2010, case C-208/og, Sayn-Wittgenstein.

4 See, i.a., de Groot, G.-R., and Vink, M. (2008). Meervoudige nationaliteit in Europees perspectief: een landenvergelijkend overzicht, Voorstudie voor de Adviescommissie voor Vreemdelingenzaken. Den Haag: ACVZ; Faist, T., ed. (2007). Dual Citizenship in Europe: From Nationhood to Societal Integration, Aldershot: Ashgate; de Groot, G.-R. (2006). Een pleidooi voor meervoudige nationaliteit. In: Faure and Peeters, eds, Grensoverschrijdend recht. Antwerpen/Oxford: Intersentia; de Groot, G.-R., and Schneider, H.E.G.S. (20o6). Die zunehmende Akzeptanz von Fällen mehrfacher Staatsangehörigkeit in West-Europa. In: Menkhaus and Sato, eds., Japanischer Brückenbauer zum deutschen Rechtskreis. Berlin: Duncker\&Humblot; de Groot, G.-R. (2003). The Background of the Changed Attitude of European States in Respect to Multiple Nationality. In: Kondo and Westin, eds., New Concepts of Citizenship: Residential/ Regional Citizenship and Dual Nationality/Identity. Stockholm: CEI FO.

5 See, i.a., Pfeiff, S. (2017). La portabilité du statut personnel dans l'espace européen. De l'émergence d'un droit fondamental à l'élaboration d'une méthode de la reconnaissance. Bruxelles: Bruylant; Franzina, P. (2013). The Evolving Role of Nationality in Private International Law. In: Annoni and Forlati, eds., The Changing Role of Nationality in International Law. London: Routledge; Vonk, O. (2012). Dual Nationality in the European Union. A Study on Changing Norms in Public and Private International Law and in the Municipal Laws of the Member States. Leiden/Boston: Martinus Nijhoff Publishers; Vonk O. (2011). De rol van dubbele nationaliteit voor toegang to the Unieburgerschap en voor rechts - en Forumkeuzebevoegdheid in het Europese international privaatrecht. Nederlands Juristenblad 27, pp. 176o-1766; de la Pradelle, G. (2002). Dual Nationality and the French Citizenship Tradition. In: Hansen and Weil, eds., Dual Nationality, Social Rights and Federal Citizenship in the US and Europe. New York: Berghahn Books; Verwilghen, M. (1999). Conflits de nationalités, plurinationalité et apatridie. Recueil des cours de l'Académie de droit international de la Haye, pp. 9-484.; Dethloff, N. (1995). Doppelstaatsangehörigkeit und Internationales Privatrecht. Juristenzeitung 50 (2), pp. 64-73; Boele-Woelki, K. (1981). Die Effektivitätsprüfung der Staatsangehörigkeit im niederländischen internationalen Familienrecht. Deventer: Kluwer.

6 See, i.a., Spiro, P.J. (2017). Multiple Citizenship. In: Shachar, Bauböck, Bloemraad, and Vink, eds., The Oxford Handbook of Citizenship. Oxford: Oxford University Press; Jones-Correa, M. (2001). Under Two Flags: Dual Nationality in Latin American and Its Consequences for Naturalisation in the United States. International Migration Review 35 (4), pp. 997-1029.

7 See, i.a., Bauböck, R. (2007). Stakeholder Citizenship and Transnational Political Participation. A Normative Evaluation of External Voting. Fordham Law Review 75 (5), pp. 2393-2447; Spiro, P.J. (2003). Political Rights and Dual Nationality. In: Martin, and Hailbronner, eds., Rights and Duties of Dual Nationals: Evolution and Prospects. New York: Kluwer Law International. 
State; ${ }^{8}$ and more general questions of $\operatorname{loss}^{9}$ and acquisition of nationality, ${ }^{10}$ and an independent EU citizenship. ${ }^{11}$ There is furthermore quite abundant literature concerning purely internal situations, ${ }^{12}$ which focuses either on persons who only possess the nationality of the Member State of residence, or on dual EU citizens who have never moved or have a Third Country background. ${ }^{13}$

However, free movement law as applied to dual EU citizens who have already moved is an almost forgotten issue in recent years. ${ }^{14}$ It used to be an issue of interest before $2011,{ }^{15}$ when a dual EU citizen was considered a "Super Citizen" based on the Garcia Avello case. ${ }^{16}$ At the time, Alina Tryfonidou stated

8 See, i.a., Kochenov, D. (2011). Double Nationality in the EU: An Argument for Tolerance. European Law Journal 17 (3), pp. 323-343.

9 Concerning loss of nationality there have in recent years been many publications concerning dual nationals, where it concerns deprivation of nationality on grounds of terrorist activities: i.a. de Groot, G.-R., and Vonk, O. (2015). De ontneming van het Nederlanderschap wegens jihadistische activiteiten. Tïdschrift voor Religie, Recht en Beleid 6 (1) pp. 34-53; Wautelet, P.R. (2017). Deprivation of Citizenship for "Jihadists". Analysis of Belgian and French Practice and Policy in Light of the Principle of Equal Treatment. Recht van de Islam 3o, p. 49 et seq.

10 See, i.a., Witte, N. (2014). Legal and Symbolic Membership. Symbolic Boundaries and Naturalisation Intentions of Turkish Residents in Germany. EUI Working Paper RSCAS 2014/100.

11 See, i.a., Margiotta, C., and Vonk, O. (2010). Nationality Law and European Citizenship: The Role of Dual Nationality, EUI Working Paper RSCAS 2010/66.

12 See, i.a., Tryfonidou, A. (2008). Reverse Discrimination in Purely Internal Situations: An Incongruity in a Citizens' Europe. Legal Issues of Economic Integration 35 (1), pp. 43-67; Lenaerts, K. (2011). 'Civis Europeaus Sum': From the Cross-border Link to the Status of Citizen of the Union. Online Journal on Free Movement of Workers within the European Union 3 (6), pp..

13 Groenendijk, K. (2014). Reverse Discrimination, Family Reunification and Union Citizens of Immigrant Origin. In: Guild, ed., The Reconceptualization of European Union Citizenship. Leiden: Brill, pp. $173^{-176 .}$

14 It is considered in some Opinions of AGs. See e.g.: Opinion of AG Sharpston delivered on 3o September 2010, case C-34/og, Ruiz Zambrano; Opinion of AG Kokott delivered on 25 November 2010, case C-434/og, Shirley McCarthy; Opinion of AG Sharpston delivered on 12 December 2013, case C-456/12, O, B, S and G; Opinion of AG Szpunar delivered on 20 May 2014, case C-202/13, Sean Ambrose McCarthy; Opinion of AG Bot delivered on 30 May 2017, case C-165/16, Lounes.

15 On 5 May 2011 the Court of Justice rendered the ruling in case C-434/o9, Shirley McCarthy.

16 Court of Justice, judgment of 2 October 2003, case C-148/o2, Garcia Avello. After Garcia Avello, Thomas Ackermann had argued that a dual EU citizen could never fall within a purely internal situation as long as (s)he had residence in an EU Member State. Dimitry Kochenov wrote that "[a]ll of them [read: dual EU citizens] are now within the scope ratione materiae of EU law whatever happens". After Shirley McCarthy, Janek Nowak stated that this was obviously not the case. See: Ackermann, T. (2007). Case C-148/o2, Carlos Garcia Avello v. Etat Belge. Common Market Law Review 44 (1), pp. 141-154, 146; Kochenov, D. (2010). Citizenship Without Respect: The EU's Troubled Equality Ideal. Jean Monnet 
quite clearly what seemed to be on the minds of many scholars dealing with dual citizens and reverse discrimination: "In my view, reverse discrimination is discrimination based on the ground of 'non-contribution to the internal market'. This is due to the fact that, in cases of reverse discrimination, the only person/traders that are disadvantaged and discriminated against are those that rely on EC law against their own Member State and cannot show the existence of the requisite link with the fundamental freedoms". ${ }^{17}$ Since dual EU citizens can establish an intracommunity connection from their other Member State's nationality, they are able to rely on Community law; hence free movement law applies to them in all cases. Indeed, at the time this could have been validly argued based on the existing case-law. However, with the Shirley McCarthy case, things changed, and have, nearly unnoticed, become worse and worse for dual EU citizens. ${ }^{18}$

One can now find statements like "[w]ith dual citizenship, migrants can freely pursue economic opportunity in states of original and adopted citizenship, a benefit to growing numbers of circular migrants". ${ }^{19}$ This is correct, but solely for the dual citizen, not for his Third Country National (TCN) family members, because all applicable laws concerning family reunification would be national legislation, and not derived rights from EU law. That is, until Lounes was decided by the Court. ${ }^{20}$

In this Chapter, a couple of constellations of movement of dual EU citizens will be discussed, introduced by explaining beforehand the system of ranking, movement, and the mobility quality. Special attention will first be given to the "right to return" case-law, where the Court created a double condition, which has detrimental effects on dual EU citizens moving between the Member States of nationality. ${ }^{21}$ Thereafter, the Lounes constellation will be explained,

Working Paper 8/2010, p. 47; Nowak, J.T. (2010). Case C-34/o9, Gerardo Ruiz Zambrano v. Office National de L'Emploi (Onem) \& Case C-434/og, Shirley McCarthy v. Secretary of State for the Home Department. ColumbiaJournal of European Law 17 (3), pp. 673-704, 703.

17 Tryfonidou, A. (2009). Reverse Discrimination in EC Law. Alphen aan de Rijn: Kluwer Law International, p. 19.

18 Tryfonidou, A. (2012). Redefining the Outer Boundaries of EU Law: The Zambrano, McCarthy and Dereci Trilogy. European Public Law 18 (3), pp. 493-526, 511.

19 Spiro, P.J. (2017), Multiple Citizenship, cit., p. 635.

20 Court of Justice, judgment of 14 November 2017 , case C-165/16, Lounes. See also on the case with a different analysis: Gualco, E. (2018). Is Toufik Lounes Another Brick in the Wall? The CJEU and the On-going Shaping of the EU Citizenship. European Papers European Forum, Insight 3 (2), pp. 911-922, available at europeanpapers.eu.

21 "Right to return" or "returners" refers to its meaning according to the case-law of the Court of Justice of the European Union on persons who resided in a Member State (of which they did not have the nationality) and then returned to the Member State of nationality. EU law grants in these cases a retention of rights which is not necessarily provided for in 
where the Court ruled on the situation of a naturalised dual EU citizen and the continued application of Art. 21 TFEU. This case has to be dissected in detail, as it creates more issues than it solves. These questions relate, first of all, to whether Lounes applies only in a Member State of naturalisation and only for as long as that naturalised dual EU citizen stays there, or whether it applies anywhere in the EU. Secondly, it has to be considered to whom the case applies. This second part relates to the mode of acquisition of the additional nationality and whether a certain genuine link has to exist in order for the case to apply. The argument continues with the question whether Lounes only applies to dual EU citizens, or whether it also applies to any other "single" EU citizens who lost the original Member State nationality upon naturalisation in another Member State. If the case were to only apply to the dual EU citizens, it is then argued that Member States would have to be restricted concerning nationality laws which establish automatic loss of nationality upon acquisition of another nationality and rules on acquisition which require a renouncement of the previously held nationality. When looking at the potential consequences of this case applying to any "single" EU citizen who had the nationality of another Member State before acquiring the one of the Member State of residence, we see a legal and practical distinction between own nationals, which is prohibited. The Court would then have no choice but to change the "right to return" case-law and to revisit cases where the nationality of another Member State was lost, leading to a loss of rights. It is concluded that the Court has to make a choice: either apply Lounes only to dual EU citizens and consequently restrict severely the competences of Member State in nationality law; or apply it to any EU citizen who has made use of the free movement rights, which means that extensive case-law has to be changed.

\section{Setting the Scene}

\section{II.1 Applicable Nationality - Ranking and Mobility Quality}

Applicable nationality is a matter of recognition of nationality, but principally a matter of giving effect to a nationality. A State has to recognise that a person has the nationality of another state based on International Law; whether it

the general provision of "right to return" in international law, as established in i.a. Art. 12, para. 4, of the International Covenant on Civil and Political Rights (ICCPR). Concerning this general right see Edwards, A. (2014). The Meaning of Nationality in International Law in an Era of Human Rights. In: Edwards and van Waas, eds., Nationality and Statelessness under International Law. Cambridge: Cambridge University Press, pp. $35^{-38}$. 
applies this nationality, which is connected to a certain set of rights, or another, which is connected to a different set of rights, is another issue. ${ }^{22}$ While in International Law, based on Nottebohm ${ }^{23}$ a genuine-link principle or mosteffective-nationality principle is applied, in EU law there is a sort of ranking of nationalities, based especially on Micheletti. ${ }^{24}$ Depending on the legal situation, be it applicable law to the name, or applicability of Directive 2004/38/EC, the ranking is different. ${ }^{25}$

One can distinguish four different ranks of nationality in EU law. These ranks are the Third Country nationality (TC), the Privileged Third Country nationality (TC+), ${ }^{26}$ the nationality of a Member State other than the Member State of residence or destination (MS) and the nationality of the Member State of residence or destination (Home MS). ${ }^{27}$

With these four ranks one can have nine different combinations of dual nationalities (see Table 5.1)

22 Permanent Court of International Justice, Nationality Decrees Issued in Tunis and Morocco, advisory opinion of 7 February 1923 .

23 International Court of Justice, Nottebohm (Liechtenstein v. Guatemala), judgment of 6 April 1955 .

24 Court of Justice, judgment of 7 July 1992, case C-369/9o, Micheletti.

25 Directive 2004/38/EC of the European Parliament and the Council of 29 April 2004 on the right of the citizens of the Union and their family members to move and reside freely within the territory of the Member States amending Regulation (EEC) No 1612/68 and repealing Directives 64/221/EEC, 68/36o/EEC, 72/194/EEC, 73/148/EEC, 75/34/EEC, 75/35/ EEC, 9o/364/EEC, 9o/365/EEC and 93/96/EEC, OJ L 158, 30.4.2004, p. 77-123.

26 A State with whom the Union has a bilateral (or multilateral) agreement which grants certain rights to its nationals. After Brexit also the UK will be part of this category, if a trade agreement is concluded. See for an overview of different TC+ Countries and rights (until 2010): Wiesbrock, A. (2010). Legal Migration to the European Union, Ten Years after Tampere. Nijmegen: Wolf Legal Publishers, p. 97 et seq. For specifically the status of citizens of the European Free Trade Association (EFTA) states, which I consider only the most privileged of the TC+, see: García Andrade, P. (2014). Privileged Third-Country Nationals and Their Right of Free Movement and Residence to and in the EU: Questions of Status and Competence. In: Guild, Gortázar Rotaeche, and Kostakopoulou, eds., The Reconceptualization of European Union Citizenship. Leiden: Brill Nijhoff, p. 111 et seq.

27 The point of view for MS and Home MS rank nationality is always the Member State where certain rights are to be applied. A dual French-German person from the point of view of the Netherlands, thus a Member State of which the person does not have the nationality, has a "MS/MS" combination of nationalities. From the point of view of France or Germany the person would have a "Home MS/MS" combination.

28 Diagonal pattern means that the person is an EU citizen. A "Home MS/Home MS" constellation for the nationality purpose is impossible, as it would mean that a person has two nationalities which are, however, of the same Member State. It is therefore shaded with a grid pattern. As will be seen for the movement factor this is different as one can move between two Member States of nationality. 
TABLE 5.1 Dual nationality combinations

\begin{tabular}{|c|c|c|c|c|}
\hline Nationality 2 & \multirow{2}{*}{$\begin{array}{l}\text { Third } \\
\text { Country }\end{array}$} & \multirow{2}{*}{$\begin{array}{c}\text { Third } \\
\text { Country } \\
+(\mathrm{TC}+)\end{array}$} & \multirow{2}{*}{$\begin{array}{c}\text { Other MS } \\
\text { (MS) }\end{array}$} & \multirow{2}{*}{$\begin{array}{c}\text { Residence/ } \\
\text { Destination } \\
\text { MS }\end{array}$} \\
\hline Nationality 1 & & & & \\
\hline Third Country & $\mathrm{TC} / \mathrm{TC}$ & & & \\
\hline Third Country+ & $\mathrm{TC}+/ \mathrm{TC}$ & $\mathrm{TC}+/ \mathrm{TC}+$ & & \\
\hline Other MS & MS/TCa & MS/TC+ & MS/MS & \\
\hline $\begin{array}{c}\text { Residence/ } \\
\text { Destination MS }\end{array}$ & $\begin{array}{l}\text { Home } \\
\text { MS/TC }\end{array}$ & $\begin{array}{c}\text { Home } \\
\text { MS/TC+b }\end{array}$ & $\begin{array}{c}\text { Home } \\
\text { MS/MSc }\end{array}$ & $\begin{array}{c}\text { Same } \\
\text { nationality }\end{array}$ \\
\hline
\end{tabular}

a Micheletti, cit.

$b$ Court of Justice, judgment of 12 March 2012, case C-7/10 and C-9/10, Kahveci and Inan.

$c$ If mover: Right to return case-law (Singh/Eind/O\&B, cit., see sections II.3 and II.4). If nonmover: Shirley McCarthy, cit. If naturalised: Lounes, cit.

Based on the case-law of the European Court of Justice it can be established that of these types of nationality, in case of application of Directive 2004/38/ EC, the Home MS's nationality is ranked highest. ${ }^{29}$ This leads to many (possible) conflicts where it concerns dual EU citizens, as the Directive might simply not be applied to the case on the ground that the dual EU citizen has the nationality of that Member State.

In EU free movement law and migration law, what is worth most is the MS rank. The MS rank takes precedence over the TC and TC+, based on the Micheletti case-law, which ruled that having the nationality of another Member State is enough to fall within the ambit of EU law. Regardless of whether the genuine-link with a TC rank nationality is greater, the MS rank always prevails.

The MS rank gives full access to the rights under the Treaties, especially Arts 20 and $21 \mathrm{TFEU}$, and access to Directive 2004/38/EC with the privileged family reunification rules concerning TCN family members. It is, however, limited by the condition that the person must have made use of his free movement rights. This I will call having activated the "mobility quality". It is furthermore limited by the requirement of having sufficient means, or by being a worker or selfemployed. If these conditions are fulfilled it is granted all rights of a Home MS rank, with only a few exceptions, like the right to vote in national elections and

29 Except when it concerns a TC+ rank national who has naturalised in the "Home MS" while retaining the $\mathrm{TC}+$ nationality. This would not lead to application of the Directive, but of that TC+ related Treaties and secondary legislation. 
protection against expulsion (which is already very limited). These exceptions are even more limited when the person gains the long-term resident status. The MS rank is, however, ranked (for the moment) lower than the Home MS. Thus, for a dual EU citizen who has both the Home MS rank and an MS rank nationality (Home MS/MS), the Home MS takes precedence.

The Home MS nationality is on the one hand ranked highest, as it takes (at the moment) precedence over the others where it concerns nationality to which effect is given concerning migration law and free movement (except against TC+ when naturalised), but worth least in EU law, as all rules applicable to it are decided by the Member State in question. These can be as limited or as generous as the Member State desires. As was stated before, the only rights that the Home MS has and the MS does not, are the rights to vote in national elections, and to absolute protection from expulsion from the Home MS. The Home MS nationality can be turned into an MS nationality i.a. by movement to an MS State, thus activating the "mobility quality". This mobility quality also functions to prevent that certain rights are lost which were previously acquired and made use of while it was an MS rank.

This rank has to be combined for certain cases with a "movement" or a change of purpose factor of the Member State ("residence" to be used in cases of naturalisation or renouncement).

There are in total twelve different types of movement, as is shown in Table $5 \cdot 2 .^{30}$

To give some examples:

- a dual EU citizen moving from a Member State of which he has the nationality, to a Member State of which he does not have the nationality is "MS/MS movement Home MS/MS"; ${ }^{31}$

- a dual EU citizen moving between the Member States of nationality is "Home MS/MS movement Home MS/Home MS"; ${ }^{2}$

30 Diagonal pattern means EU law applies, or at least to a certain extent. Horizontal pattern means EU law might indirectly apply depending on the relation between the TC+ and the EU. Vertical pattern means EU law probably does not apply. If the mobility quality was activated once in a lifetime though, it would be favourable if it continued to be effective even if an individual between residence in an MS and returning to a Home MS resides in a TC. No pattern concerns any move to a TC where EU free movement law obviously is not applicable.

31 The nationality ranks are both MS rank, as the point of view has to be the Member State of destination.

32 As the point of view of only the Member State of destination has to be taken, only one of the nationalities of the person is a Home MS rank, the other nationality is MS rank, irrespective of the fact that the person came from another Member State of nationality. For 
TABLE 5.2 Movement and residence changes

\begin{tabular}{|c|c|c|c|c|}
\hline $\begin{array}{c}\text { Previous residence/ } \\
\text { destination country }\end{array}$ & $\begin{array}{c}\text { Third } \\
\text { Country }\end{array}$ & $\begin{array}{c}\text { Third } \\
\text { Country+ }\end{array}$ & Other MS & $\begin{array}{c}\text { Residence MS } \\
\text { (home MS) }\end{array}$ \\
\hline Third Country & $\mathrm{TC} / \mathrm{TC}$ & $\mathrm{TC}+/ \mathrm{TC}$ & $\mathrm{MS} / \mathrm{TC}$ & Home MS/TC \\
\hline Third Country+ & $\mathrm{TC} / \mathrm{TC}+$ & $\mathrm{TC}+/ \mathrm{TC}+$ & $\mathrm{MS} / \mathrm{TC}+$ & Home MS/TC+ \\
\hline Other MS & $\mathrm{TC} / \mathrm{MS}$ & $\mathrm{TC}+/ \mathrm{MS}$ & $\mathrm{MS} / \mathrm{MS}$ & Home MS/MS \\
\hline $\begin{array}{c}\text { Destination MS } \\
\text { (home MS) }\end{array}$ & $\begin{array}{c}\mathrm{TC} / \mathrm{Home} \\
\mathrm{MS}\end{array}$ & $\begin{array}{c}\mathrm{TC}+/ \text { Home } \\
\mathrm{MS}\end{array}$ & $\begin{array}{c}\mathrm{MS} / \mathrm{Home} \\
\mathrm{MS}\end{array}$ & $\begin{array}{c}\text { Home MS/Home } \\
\mathrm{MS}^{\mathrm{a}}\end{array}$ \\
\hline
\end{tabular}

a It is argued in this Chapter that Lounes, cit., implies that also in a Home MS/Home MS move Art. 21, para. 1, TFEU applies.

- an EU citizen that is born and continues to reside in a Member State of which (s)he is not a national is "MS residence MS";33

- an EU citizen that naturalises in the host Member State while retaining the other Member State's nationality is "Home MS/MS residence MS/ Home MS". 34

On the contrary, when one considers the case-law of the Court on names' recognition, the Member States' nationalities are equal, and the dual EU citizen may choose between the two. A Member State can only refuse to recognise a name established by the law of the other Member State of nationality if there is an absolute constitutional prohibition. ${ }^{35}$

the movement it is different. There both the point of view of the Member State of origin and the Member State of destination have to be considered. As the EU citizen moving between Member States of nationality is considered by either as its national, it is "movement Home MS/Home MS".

33 It is "residence MS" as there is no actual movement between Member States. This is the Catherine Zhu constellation. Court of Justice, judgment of 19 October 2002, case C-200/ o2, Zhu and Chen.

34 It is "residence MS/Home MS" as before naturalisation the Member State of residence was not a Member State of nationality. With the naturalisation the function of this Member State changes, as it becomes a Home MS. "Residence" makes clear that there is no factual movement between states, but that it is a function change of the Member State of residence.

35 One has to distinguish in the case-law of the Court "absolute constitutional prohibitions" from "conditional and inconsistently applied constitutional prohibitions". Whereas the first can justify a refusal to recognise the name, the latter also has to fulfil the condition of proportionality. In my view, in the case of dual EU citizens, a conditional and especially an 


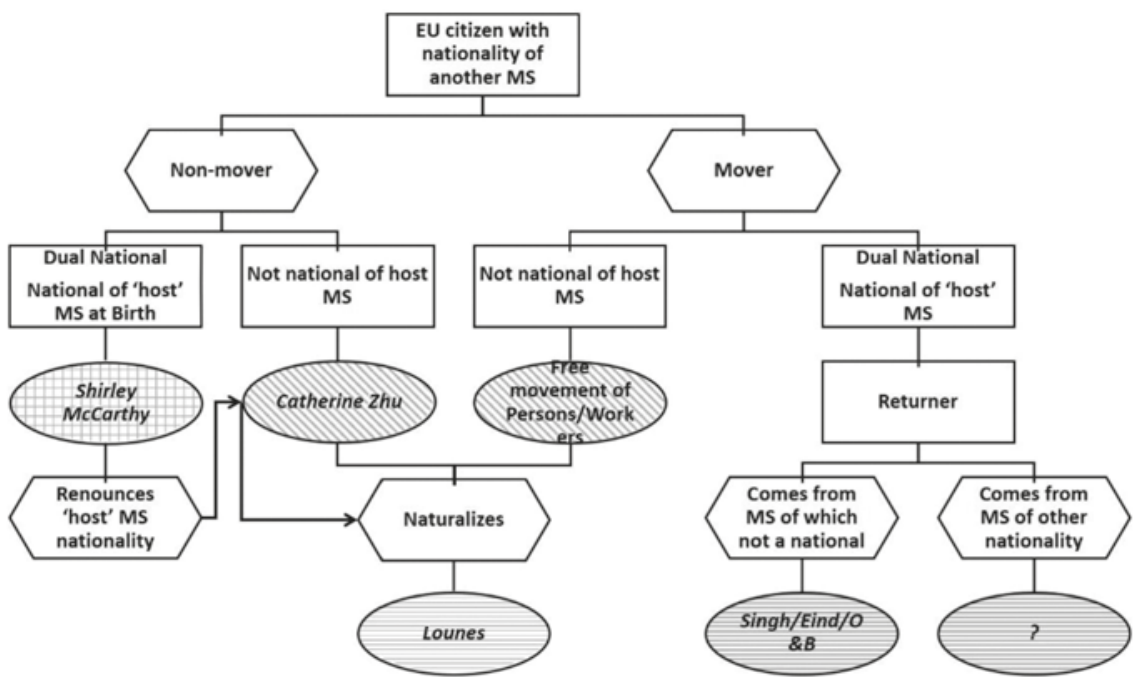

FIGURE 5.1 Applicable law to dual EU citizens

\section{II.2 Constellations}

There are many different constellations and lines of case-law in free movement law. If one considers the free movement of persons and workers, and EU citizenship cases, ${ }^{36}$ the entire setting where it concerns family reunification under Directive 2004/38/EC looks like this Picture. ${ }^{37}$

I will especially address the Lounes and the "returner" constellations.

inconsistently applied constitutional prohibition, can never justify a restriction, since it cannot be proportional. To give some examples of different types: in Sayn-Wittgenstein it concerned an absolute constitutional prohibition; in Bogendorff von Wolffersdorff it concerned a "conditional constitutional prohibitions" and in Runevič-Vardyn it concerned an inconsistently applied constitutional prohibition.

36 I exclude here case-law like Carpenter which is in free movement of services and technically could apply to a dual national living in the Member State of nationality, if one compares them to persons having only the nationality of the Member State of residence (Court of Justice, judgment of 11 July 2002, case C-6o/oo Carpenter). Carpenter would add thus an additional category to "Non-Mover" - "Dual National-National of the host MS at Birth" => "Grant Services abroad", if the answer is yes Carpenter applies, if the answer is no, Shirley McCarthy would apply. However, if services are provided abroad that means that there must be sufficient means or that the person is a worker or self-employed. In the argumentation used in this Chapter, this should be already enough to make a Shirley McCarthy case a Catherine Zhu constellation by ranking the other MS nationality higher than the Home MS nationality.

37 To explain the shapes and colours of the boxes: Shapes: $a$ ) Square means a characteristic of the person, like nationality; $b$ ) Oval/Round means applicable law or case-law; $c$ ) 


\section{II.3 Right to Return - Conditions (Home MS(/MS) Movement MS/ Home MS)}

In $O$ and $B^{38}$ the Court in essence set out three conditions ${ }^{39}$ for the right to return, ${ }^{40}$ which have to be fulfilled next to the exhaustive list of documents required based on Art. 8, para. 2, and Art. 10, para. 2, of the Directive, which is applicable by analogy: ${ }^{41}$

a) the Union citizen made use of his free movement rights under the Directive by application of Art. 7, para. 1, or even Art. 16, para. 1, of the Directive; ${ }^{42}$

b) the family life must have been established, or the TCN must have joined the Union citizen while the Union citizen was exercising his rights under Art. 7, para. 1, or Art. 16, para. 1 ; $^{43}$

c) the family member must have had residence in the host Member State based on Union law, specifically Art. 7, para. 2, or Art. 16, para. 2, of the Directive. $^{44}$

The $O$ and $B$ case is considered to facilitate circular migration. This is, however, only true to the extent that it concerns a person who comes from a Member State of which he is not a national. When it concerns a dual EU citizen coming from a Home MS, who is moving to another Home MS, $O$ and $B$ is anything but a facilitator; it is indeed an impediment.

Hexagon means (non-)action by the person; Patterns: a) Diagonal (Catherine Zhu and Free movement of Persons/Workers) means EU Free movement lawfully applicable (incl. Directive 2004/38/EC); b) Vertical (Shirley McCarthy) means purely internal situation; $c$ ) Horizontal means applicability of EU Free movement law is (yet) unclear (?) and EU free movement law is only in so far applicable that it has been used before (thus Directive 2004/38/EC applicable by analogy: Singh/Eind/O and B). In the case of Lounes the horizontal pattern is looser because the rule that the rights must have been used before does not apply. In the schematics the person always has the nationality of another Member State, thus MS rank nationality. If Catherine Zhu had theoretically at birth somehow been granted several other Member State nationalities, but not the one of residence (thus MS/ MS rank), the situation would have been the same.

38 Court of Justice, judgment of 12 March 2004, case C-456/12, $O$ and $B$.

39 Ibid., para. 57.

40 Previous case-law on the right to return: Court of justice, judgment of 7 July 1992, case C-370/9o, Singh; Court of Justice, judgment of 11 December 2007, case C-291/05, Eind. See also: Berneri, Ch. (2017). Family Reunification in the EU: The Movement and Residence Rights of Third Country National Family Members of EU Citizens. Oxford/ Portland: Bloomsbury Publishing, especially pp. 43-63; Spaventa, E. (2015). Family Rights for Circular Migrants and Frontier Workers: $O$ and $B$, and $S$ and G. Common Market Law Review $5^{2}$ (3), pp. $753^{-} 777$.

$41 O$ and $B$, cit., para. 5 .

$42 \quad I b i d$., paras. $5^{1}$ and 56.

43 Ibid., paras. 54-55.

44 Ibid., para. 54. 


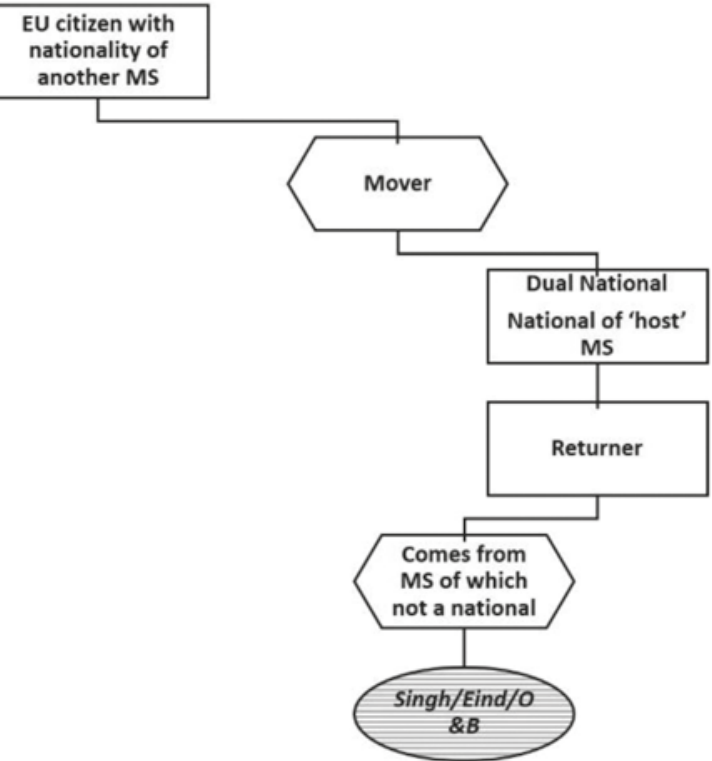

FIGURE 5.2 Constellation right to return from MS

\section{II.4 “Circular" Right to Return - (Home MS/MS Movement Home MS/ Home MS)}

In $O$ and $B$, the Court seems to have forgotten to take into account dual nationals and how its case-law applies to them. The reason is that the Court wanted to emphasise an issue concerning the Shirley McCarthy case. This concerned the application of the Directive to nationals of the Member State of residence.

The Court stated that "[i]t follows from a literal, systematic and teleological interpretation of Directive 2004/38 that it does not establish a derived right of residence for third-country nationals who are family members of a Union citizen in the Member State of which that citizen is a national". 45 From a teleological interpretation, the Court argues that the aim of the Directive is to "facilitate and strengthen the exercise of the primary and individual right to move and reside freely within the territory of the Member States" as is stated in Art. 1, let. a), of the Directive.

Here, the Court emphasises the point that one is actually exercising that right. ${ }^{46}$ By "move", the Court seems to mean a movement within the territory

$\begin{array}{ll}45 & \text { Ibid., para. } 37 . \\ 46 & \text { Ibid., para. } 41 .\end{array}$




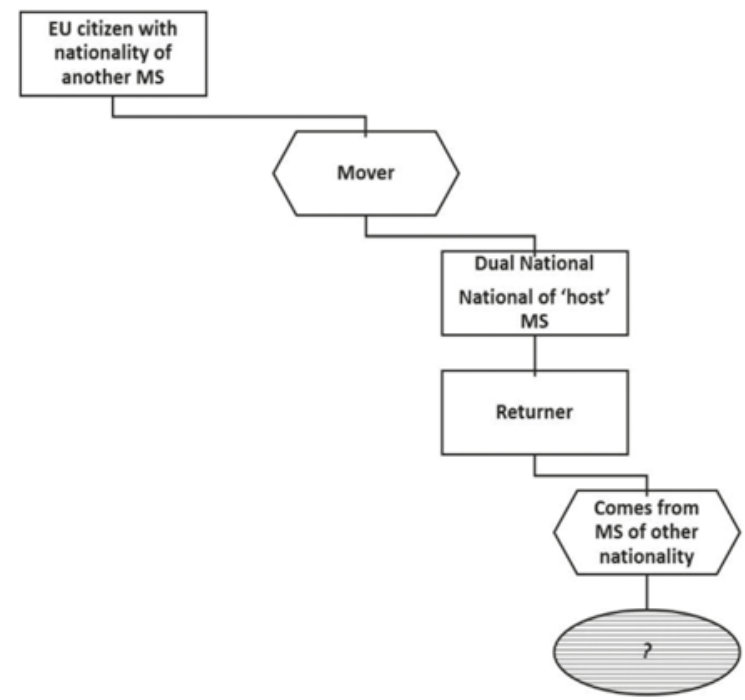

FIGURE 5.3 Constellation right to return from home MS

of the Union, and "reside" refers to the territory of all the Member States minus one, the Home Member State.

The Court also mentioned that, because international law does not allow a State to refuse to its own nationals the right to enter and remain there, the Directive only applies to cases where the Union citizen wants to enter a Member State of which he is not a national. ${ }^{47}$ Thus, the Court states that "Directive $2004 / 38$ is therefore also not intended to confer a derived right of residence on third-country nationals who are family members of a Union citizen residing in the Member State of which the latter is a national". ${ }^{48}$ Derived rights of residence for a TCN family member of a Union citizen who resides in a Member State of nationality would only be possible in some circumstances based on Art. 21 TFEU. ${ }^{49}$ As stated before, the Directive would apply by analogy in these cases, but not directly.

There is a serious problem here when one considers dual nationals. The Court has made the right to return conditional upon the Directive having already been applicable before, while it has made the Directive conditional upon not having the nationality of the "host" Member State. This double condition can only affect dual EU citizens in a negative way.

$\begin{array}{ll}47 & \text { Ibid., para. } 42 . \\ 48 & \text { Ibid., para. } 43 . \\ 49 & \text { Ibid., para. } 44 .\end{array}$


Let's consider a dual German-Romanian national who was born and grew up in Germany. At a certain moment, this person moves to Romania and works there for a couple of years. In this period, he marries a TCN. Because he has Romanian nationality, the authorities do not allow family reunification based on the Directive, but they are kind enough to give a national residence permit to the spouse. After some time in Romania, the couple decide to go to Germany. The German authorities, however, refuse the right to return on the following grounds, based on the previous three criteria set out:

a) the EU citizen did not have a residence right in Romania based on Art. 7 , para. 1, of the Directive, but an autonomous right because he is a Romanian national;

b) because the EU citizen did not have an Art. 7, para. 1, based residence right, the TCN spouse is considered not to have joined him while he was exercising this right;

c) consequently, the TCN spouse did not have an EU residence permit under Art. 7, para. 2, or Art. 16, para. 2, but merely a national residence permit.

As the Directive has never been applicable to the case, it can also not be applied by analogy.

This constellation highlights the challenge for circular migrating dual EU citizens.

First of all, the fact that the dual citizen is not considered to be exercising his rights under Art. 7, para. 1, of the Directive while he is moving to another Member State. If he had not had Romanian nationality, this would clearly have been an Art. 7, para. 1, residence. Only the fact that he is a dual national puts him in a disadvantaged position.

The second point is the specific condition that the Court imposed, that the TCN family member must have had a derived residence right under Art. 7, para. 2, and Art. 16, para. 2, of the Directive. What if the TCN has a residence right on his own, like a blue card or national residence card? In Eind the Court stated that:

Community law does not require the authorities of that State [the home Member State] to grant a right of entry and residence to a third-country national who is a member of that worker's family because of the mere fact that, in the host Member State where that worker was gainfully employed, that third-country national held a valid residence permit issued on the basis of Article 10 of Regulation No 1612/68.50 
The national authorities could, therefore, just ignore this fact.

As the Court of Justice seems to believe that the Directive does not apply in such cases of dual nationals moving between the Member States of which they are nationals, it would also be highly doubtful whether it would consider Art. 7 of the Charter of Fundamental Rights of the European Union (Charter) to be applicable in such a case. This happens despite the fact that there is an obvious cross-border element, and in all other cases the Directive, meaning an implementing act in the sense of Art. 51, para. 1, of the Charter, would be applicable.

It is very unfortunate that this case of the dual German-Romanian national is not just a theoretical scenario meant to describe the disadvantages for dual nationals, but it is an actual case from 2016 where the Bayerischer Verwaltungsgerichtshof had to decide on a family reunification case with a dual German-Romanian citizen who had lived his entire life in either Germany or Romania. ${ }^{51}$ The Court considered it unclear, though it refrained from referring a preliminary question to the Court of Justice, whether a person who has the nationality of two Member States and moves from one to the other in order to work, has made use of his free movement rights and whether - upon returning to the first Member State after four years - the right to return also applies. ${ }^{52}$ The uncertainty about this was based upon the reason that the dual EU citizen had always lived in a Member State of which he has the nationality. ${ }^{53}$

Let's consider now that this German-Romanian dual EU citizen moved first to Greece and benefited from family reunification there based on the Directive, which is applicable because he is not a national of Greece. He then moves to Romania, and the Directive applies by analogy, and therefore family reunification is granted. But if he would move then from Romania to Germany, would the Directive, which was applicable by analogy in Romania, again be applicable by analogy?

The entire situation looks even more curious if one considers another German-Romanian, Mircea Florian Freitag, who moved between both Home Member States in order to have his name changed to the original Romanian version, which he wanted to be recognised in Germany, his other state of nationality. His case was decided only recently, in June 2017.

$5^{1} \quad$ Administrative Court of Munich, judgment of 20 January 2016, 10 C 15.723.

$5^{2} \quad$ Ibid., para. 46.

53 Germany has altered its administrative guidelines in the meantime concerning this aspect to allow the applicability of the free movement rights. Administrative Guidelines on the Implementation of the Freedom of Movement Act of 3 February 2016 (Germany), Allgemeine Verwaltungsvorschrift zum Freizügigkeitsgesetz/EU, section 1.4.2. 
In Freitag, the Court stated that "[a]ccording to settled case-law, a link with EU law exists in regard to nationals of one Member State lawfully resident in the territory of another Member State [...].That is the case as regards the applicant in the main proceedings, who is a Romanian national and is resident in the territory of the Federal Republic of Germany, of which he is also a national". ${ }^{44}$ Furthermore, the Court considered that making recognition of the name established by another Member State conditional upon having the habitual residence there - which means in essence that Art. 7, para. 1 , of the Directive is applicable to the person - is a restriction of the free movement rights. ${ }^{55}$

The Court therefore states the opposite in Freitag, where it concerned names, from what it ruled in $O$ and $B$, where it concerned family reunification. This issue has now been addressed in Lounes.

\section{II.5 Naturalisation - Lounes (Home MS/MS Residence MS/Home MS)}

On 14 November 2017, the Court of Justice gave its judgment in the Lounes case, which concerns a person who has the nationality of one Member State, moved to another Member State, and naturalised there while retaining the first Member State's nationality. The question addressed to the Court was whether Directive 2004/38/EC would still apply to that person after naturalisation. The Court of Justice had to make a choice between two lines of case-law:

a) the "right to return" case-law, which would mean that the Directive ceased to be applicable to the person upon naturalisation, and only rights previously made use of (e.g. family reunification was applied for before naturalisation) would be retained by analogy. This is a logical option, since the only difference between the right to return and naturalisation is that the "movement" change is replaced by a "residence factor" change; or

b) the TC+ naturalisation cases, where it was decided that preferential rights on migration acquired under the legal framework applicable to nationals of a TC+ continue to be applicable after naturalisation. ${ }^{56}$

This second option concerns the Kahveci and Inan case-law. ${ }^{57}$

As was explained concerning the ranking, privileged Third Countries are called here TC+. This does not mean that each of these countries has the same rights. Some have more than others. Swiss citizens have, due to the Bilateral Treaties, nearly equal rights with EU citizens, and the same applies to nationals

$54 \quad$ Freitag, cit., para 34.

55 Ibid., para. 39 .

56 Meaning, cases concerning persons who had at naturalisation the nationality of a TC+ and who were able to retain this other nationality. 


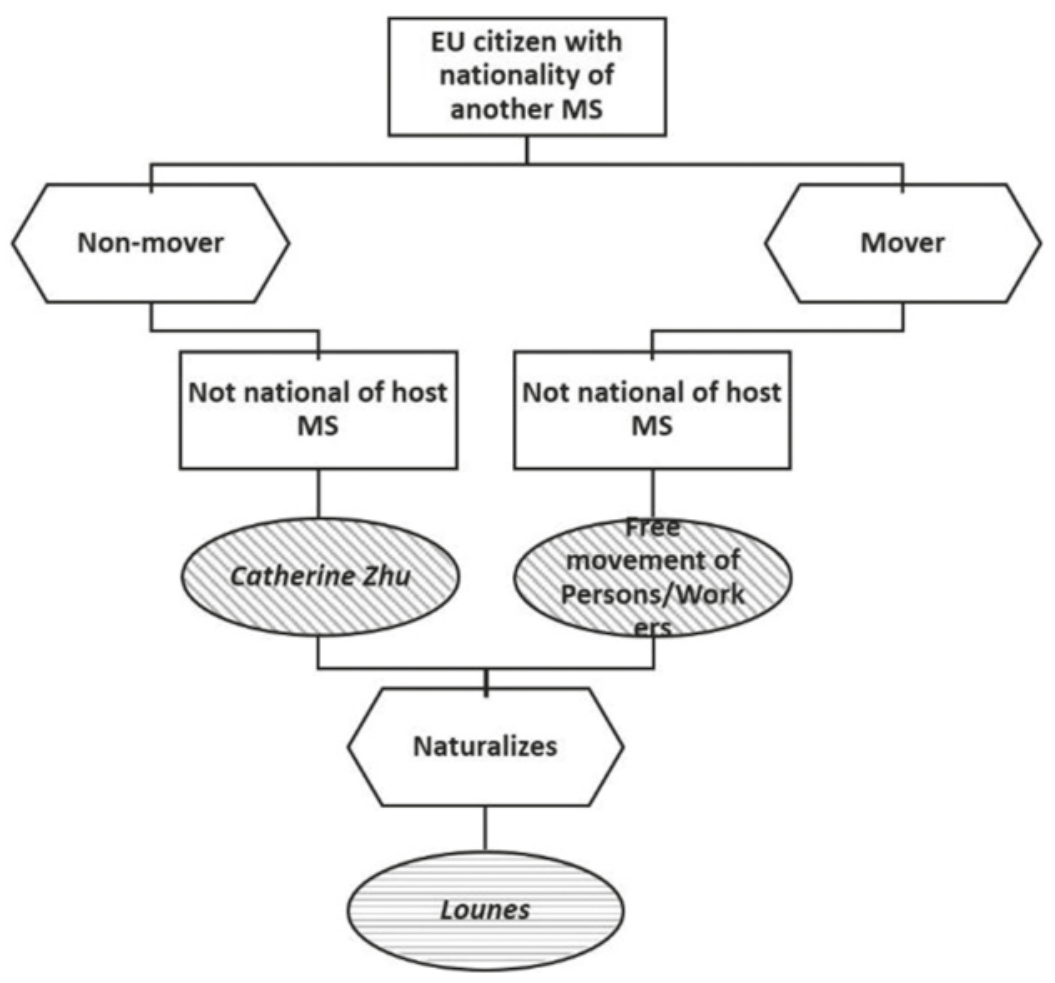

FIGURE 5.4 Constellations lounes

of the EEA States. ${ }^{58}$ Others have fewer rights but are still quite privileged, such as Turkish nationals who benefit from the EEC-Turkey Association Agreement $^{59}$ and Decision $1 / 80 .{ }^{60}$

58 I.a. Agreement between the European Community and its Member States, of the one part, and the Swiss Confederation, of the other, on the free movement of persons - Final Act Joint Declarations - Information relating to the entry into force of the seven Agreements with the Swiss Confederation in the sectors free movement of persons, air and land transport, public procurement, scientific and technological cooperation, mutual recognition in relation to conformity assessment, and trade in agricultural products.

59 Agreement establishing an Association between the European Economic Community (EEC) and Turkey, signed at Ankara on 12 September 1963 by the Republic of Turkey and by the Member States of the EEC and the Community and concluded, approved and confirmed on behalf of the Community by Council Decision 64/732/EEC of 23 December 1963 .

6o Decision $1 / 8$ o of the Association Council of 19 September 1980 on the development of the Association. 
In Kahveci and Inan, the question was whether a Turkish national could still invoke Decision 1/80 after he had acquired the nationality of the host State, in casu the Netherlands, while retaining Turkish nationality. ${ }^{61}$ The Court stated that "[a] rule [...] providing that the rights conferred by the first paragraph of Article 7 of Decision No 1/80 can no longer be relied upon where the Turkish worker who is already legally integrated in the host Member State has obtained Netherlands nationality, would have precisely the effect of undermining the legal status expressly conferred on Turkish nationals by the law resulting the EEC-Turkey Association Agreement". ${ }^{62}$ Here, the Court made a similar argumentation as in Micheletti, though in this case, ironically, the third-country nationality gained preference, as more rights were attached to it than to having the nationality of the host State. The Court concluded that "Article 7 of Decision No 1/80 must be interpreted as meaning that the members of the family of a Turkish worker duly registered as belonging to the labour force of a Member State can still invoke that provision once that worker has acquired the nationality of the host Member State while retaining his Turkish nationality". ${ }^{3}$ This, however, only applies to cases where the TC+ rights concern family reunification, and not to other rights, such as social security. ${ }^{64}$

The reasoning behind this decision of the Court was that, if integration results in the loss of rights, this would lead to discouraging $\mathrm{TC}+\mathrm{s}$ from pursuing the ultimate form of integration, "naturalisation".65

In his Opinion on Lounes, AG Bot comes, to a certain extent, to the same conclusion as the Court in Kahveci and Inan. ${ }^{66}$ However, he makes things rather confusing, by not referring to this case-law. ${ }^{67}$ Instead, he first applies option

61 It thus involved a "Home MS/TC+ residence MS/Home MS" constellation. It is not entirely clear whether the applicants had actually retained Turkish nationality or reacquired it while retaining the Dutch nationality. There is in the Netherlands a renouncement requirement of the previous nationality upon naturalisation, which can be waived in case it is (nearly) impossible to lose the other nationality. This is what might have happened. What is also possible is that they reacquired Turkish nationality while retaining the Dutch nationality which is also possible, through a derogation of the rule on automatic loss of nationality upon acquisition of another nationality if one is born there or it is the nationality of the spouse.

$62 \quad$ Kahveci and Inan, cit., para. 38.

63 Ibid., para. 41.

64 This was at issue in Court of Justice, judgment of 11 November 1999, case C-179/98, Mesbah. See for this distinction: Kahveci and Inan, cit., para. 34.

65 Kahveci and Inan, cit., paras. 33 and 35.

66 Opinion of AG Bot, Lounes, cit.

67 In its judgment, the Court of Justice also did not refer to this case-law although it quite obviously was inspired by it. 
1, coming to the conclusion that only rights attained before naturalisation can still be applied, but then changes his mind. ${ }^{68}$

If the Court had decided for option 1, this would have led to a consistent application of case-law unfavourable to dual EU citizens - unfavourable, but at least consistent. Still, this would mean that a naturalised TC+ would have more rights than a naturalised person who already was an EU citizen before.

Option 1 would have been especially problematic in the light of Brexit, because it would also mean that a person who naturalised in one Member State, who retained the nationality of another Member State - that has withdrawn from the Union under Art. $50 \mathrm{TEU}$ and has negotiated a preferential trade agreement with the EU, including certain free movement rights - would suddenly be in a better position in the Home MS, than when (s)he was a dual EU citizen, since the person would be a TC+. This certainly cannot have been the intended outcome.

The Court decided for option 2, and thus made the other Member State's nationality effective concerning the application of Directive 2004/38/EC in a Home Member State; this leads to a situation where it is utterly unclear when the Directive is applicable to a dual EU citizen. This gives rise to questions such as "would it only apply to naturalised dual EU citizens, to the detriment of dual EU citizens who have both nationalities since birth?" or "can this second group get into the same situation by moving to another Member State, returning, and having a life-long application of the Directive; or only for a certain period? And what if they renounce one nationality, and then reacquire it?".

\section{Lounes Judgment}

\section{III.1 Dual Nationality and the Directive-Home MS Rank Always Applicable}

Concerning the Directive, the Court considered that the purpose of it is to "facilitate the exercise of the primary and individual right to move freely within

68 Though, he also comes to a similar conclusion, while stating that Art. 21 TFEU should be applied because it would be conflicting with integration. The AG stated that " $\mathrm{t}] \mathrm{o}$ continue the family life which she has started, she would then be forced to leave that State [state of naturalisation] to move to another Member State in order to be able to claim once again the rights conferred by Directive 2004/38 and, in particular, the possibility of residing with her spouse". For Mrs Garcia Ormazabal and Mr Lounes this does not change the situation at all. Mrs Garcia Ormazabal and Mr Lounes did not have a family life before her naturalisation, but only four years afterwards. According to the facts she naturalised on 12 August 2009 and Mr Lounes only arrived in the UK in January 2010. Only in 2013 did they begin a relationship and married in 2014. Opinion of AG Bot, Lounes, cit., paras. 21-22. 
the territory of the Member States", a right that is granted to EU citizens. Family members of these citizens have a derived right. However, the Court confirmed here that TCN family members cannot derive any autonomous rights from the Directive. ${ }^{69}$ The Court furthermore reiterated what it had stated in $O$ and $B$, that through a "literal, contextual and teleological interpretation", the Directive does not confer a derived right of residence to TCN family members of an EU citizen in his Home MS. The Court once again considered that the wording used in the Directive - "Member State other than that of which they are a national", "another Member State" and "host Member State" - clearly indicates that it is not supposed to be applicable in a Member State of which the person is a national. ${ }^{70}$ The Court also stated that the Directive only governed the exercise of the free movement rights (and consequently not the retention of these rights). ${ }^{71}$

Moreover, the Court considered that the Directive is not intended to grant the right of entry and residence in the Home MS since, based on a principle of international law, a Member State cannot refuse such a right to its own nationals. Since the EU citizen already has an unconditional right of residence in the Member State of nationality, the Directive is consequently not intended to grant a derived right of residence to the TCN family members of such a person. ${ }^{72}$

Applying these considerations to the case, the Court concluded that there is no doubt that Mrs García Ormazábal had indeed exercised her right of free movement when she moved to the UK, as a Spanish national. She therefore had held the status of beneficiary under Art. 3, para. 1, of the Directive and had resided there based on Art. 7, para. 1, and even Art. 16, para. 1, of the Directive. However, this had changed when she naturalised. According to the Court the "acquisition of British citizenship gave rise to a change in the legal rules applicable to her, under both national law and the directive". ${ }^{73}$ From the moment of naturalisation she ceased to be a beneficiary for the purpose of the Directive,

69 This is actually not entirely correct. Art. 13, para. 2, of the Directive concerns the retention of the right of residence by a TCN family member in case of divorce, annulment of marriage or termination of the registered partnership. Under the conditions set in that article, the residence is retained. The article furthermore states that "[s] uch family members shall retain their right of residence exclusively on personal basis". One cannot but understand this "exclusively on personal basis" as meaning that it concerns an autonomous right.

$70 \quad$ Lounes, cit., paras. 34-35.

71 Ibid., para. 36 .

$72 \quad$ Ibid., para. 37 .

73 Ibid., paras. $38-39$. 
as her residence was no longer a conferred right, but an inherently unconditional right under national law. ${ }^{74}$

The fact that she still had Spanish nationality, or that she had exercised her free movement rights did not change this. The Court considered that, despite these conditions, Mrs García Ormazábal had, since her naturalisation, no longer "been residing in a 'Member State other than that of which [she is] a national ". ${ }^{75}$ Consequently, the Directive is not applicable to the Home MS/MS combination as the Home MS rank gains preference.

Thus far, the judgment is not very surprising; the statements made by the Court concerning Art. 21, para. 1, TFEU are, however, far-reaching.

\section{III.2 Dual Nationality and Art. 21, Para. 1, TFEU}

Concerning Art. 21, para. 1, TFEU the Court considered, first, that just like the Directive, Art. 21, para. 1, TFEU does not grant an autonomous right of residence to the TCN family member of an EU citizen, but only a derived right of residence. The "purpose and justification" for this derived right are based on the fact that the refusal would interfere with the free movement rights, its exercise, and its effectiveness accorded to the EU citizen. ${ }^{76}$

The government of the UK argued that it concerned a purely internal situation. The Court disagreed with this, considering that a situation where an EU citizen has made use of the free movement rights by residing legally in another Member State cannot be treated as a purely internal situation solely on the ground that the person has acquired the nationality of the Member State of residence. The Court emphasised, referring to Freitag, that it "has already held that there is a link with EU law with regard to nationals of one Member State who are lawfully resident in the territory of another Member State of which they are also nationals".77

The Court went on, stating that a dual EU citizen who has exercised the free movement rights by moving to a Member State other than "the Member State of origin", may rely on the rights pertaining to EU citizenship "also against one of those two Member States", meaning the Member States of nationality. This specifically includes, according to the Court with reference to Metock, the right "to lead a normal family life, together with their family members, in the host

74 Read the purpose of the Member State of residence has changed concerning the movement and residence indications as explained in section II.1.

75 This means that the Home MS rank nationality gains priority over the MS rank nationality for the purpose of the Directive, irrespective whether the mobility quality was activated.

$7^{6}$ Lounes, cit., paras. $45^{-48}$.

77 Ibid., paras. $49^{-} 5$ o. 
Member State". Denying this right to a dual EU citizen who has naturalised in the Member State of residence would undermine the effectiveness of Art. 21, para. 1 , TFEU. ${ }^{78}$

The Court then provides several grounds for this.

First of all, denying this right would place Mrs García Ormazábal in the same situation as Shirley McCarthy, who had not made use of the free movement rights.

Secondly, the rights conferred by Art. 21, para. 1, TFEU are intended for integration into the host Member State. Naturalisation is the show of intent "to become permanently integrated in that State". It would be illogical, according to the Court, that an EU citizen who has acquired rights by making use of the free movement rights, would have to "forego those rights" because (s)he wants to naturalise in order to be more deeply integrated into the society of that State. ${ }^{79}$

The Court further stated that an EU citizen who had acquired the nationality of the Member State of residence next to the original Member State nationality would be treated less favourably for the purpose of family life than the EU citizen who holds only the nationality of origin. The Court considered that these rights "would thus be reduced in line with their increasing degree of integration in the society of that Member State and according to the number of nationalities that they hold". 80 The last part of the sentence is rather cryptically formulated - one should consider for this the situation described above concerning the consequences of Option 1 (applying $O$ and $B$ strictly to the case), which would result in a situation where a person having the nationalities of every Member State would never be able to derive rights from the Directive and consequently from EU law.

The Court concluded that a person who naturalised in the Member State of residence, while retaining the original nationality of another Member State, should be able to continue to enjoy the rights derived from Art. 21, para. 1, TFEU, especially the right to "build a family life" with the TCN spouse, by means of a derived right of residence for the spouse. The conditions for granting this derived right of residence should not be stricter than those provided for in the Directive, as was already stated in $O$ and $B .{ }^{81}$

\footnotetext{
$7^{8}$ Ibid., paras. $5^{1-53}$.

79 Ibid., paras. $5^{6-58}$. It is very remarkable, that the Court did not make any reference on this point to Kahveci and Inan, cit., while the argumentation is identical and the wording extremely similar.

8o Lounes, cit., para. 59 (emphasis added).

81 Ibid., paras. 6o-61.
} 


\section{III.3 Discussion}

This case is interesting from many points of view.

Essentially, the Court ruled that a dual EU citizen who has made use of free movement rights can always rely on Art. 21, para. 1, TFEU, even in a Home MS, and that this includes Metock-type situations. Therefore, the TCN family member does not need to have had prior legal residence in the EU to have a derived right of residence in the Home MS. The Court further confirmed the theory presented in this Chapter, of giving effect to nationality and the mobility quality.

It is curious, though, that for certain issues, and especially concerning the integration argument, the Court seems to draw considerable inspiration from Kahveci and Inan, but does not refer to it at all. This is even more surprising considering that the referring Court had explicitly relied on this case.

It also left both Shirley McCarthy and $O$ and $B$ standing in full, which will cause some new legal questions, as will be explained below.

a) For the Directive: Home MS rank nationality highest. As regards giving effect to nationality according to the Directive, the Court made it absolutely clear with its detailed analysis that the Home MS rank nationality gains absolute priority over any other nationality. With this, the Court limited Shirley McCarthy even further, by excluding the MS rank nationality of a dual EU citizen from being applicable to the Directive in a Home MS, even if they have made use of their free movement rights. ${ }^{82}$ As explained above in section II.4, the Court had already done this in $O$ and $B$, but without direct reference to it also being applicable to dual EU citizens.

Thus, the Court has now confirmed that the Directive is not applicable in a situation such as above, concerning circular dual EU citizens moving between the two Home MS. This is the case even if the first move is to the other Home MS, and where no other link exists with that Member State except for the nationality.

b) Confirmation of giving effect to a nationality and the mobility quality. As the Directive is not directly applicable, one has to check whether the mobility quality is activated, which puts the MS rank nationality above the Home MS rank nationality, for the purpose of Art. 21, para. 1, TFEU.

82 In Shirley McCarthy, cit., para. 39, the Court still concluded that "in so far as the Union citizen concerned has never exercised his right of free movement and has always resided in a Member State of which he is a national, that citizen is not covered by the concept of 'beneficiary' for the purposes of Art. 3(1) of Directive 2004/38, so that that directive is not applicable to him" (emphasis added). This "in so far as" could be considered as a limitation that excluded her from the scope. With Lounes it is now confirmed that even if she had made use of the free movement rights Shirley McCarthy would not have been covered directly by the Directive. 
The Court stated in Lounes that "[a] Member State cannot restrict the effects that follow from holding the nationality of another Member State, in particular the rights which are attendant thereon under EU law and which are triggered by a citizen exercising his freedom of movement". 83 This as such is nothing new, considering that in Micheletti and in Zhu and Chen the Court had already stated that a Member State cannot restrict the rights derived from an MS rank nationality. The rights are thus attached to the MS rank nationality and are "triggered" by the exercise of free movement rights, which means the mobility quality becomes activated.

IV

"New" Issues

There are some problems in this judgment, with possibly large implications, because on some points, the Court was not very clear, while on others, it was too detailed.

This especially concerns the type of nationality acquisition and retention of the other MS nationality.

In its conclusion, the Court set out certain conditions. These were based on the manner in which the questions had been phrased by the referring Court. The Court should maybe have deviated a bit from this, since it makes certain issues unclear, meaning that these conditions will have to be reinterpreted at a later stage.

The Court stated that a TCN family member of an EU citizen who:

a) has made use of the free movement rights, specifically Art. 7, para. 1, or Art. 16, para. 1, of the Directive; and

b) has acquired the nationality of the Member State of residence; and

c) has retained the nationality of the other Member State; and

d) marries several years later with the TCN; and

e) continues to reside in "that Member State", meaning the Member State of naturalisation, has no right of residence under the Directive, but has that right under Art. 21, para. 1, TFEU for which the conditions on entry and residence may not be stricter than under the Directive.

Here, the Court was too specific and there will surely be national courts who will interpret this as follows: "It is now clear that a dual EU citizen who has moved to another Member State and who acquires that Member States nationality, while keeping his first nationality, still has the rights accorded to him by the Directive by analogy afterwards in the Member State of naturalisation".

Lounes, cit., para. 55 . 
In all other situations, this right of residence might be refused, even though this would be a very narrow and incorrect interpretation of Lounes.

Instead, the Court should have stated something like:

- The Directive is never applicable to an EU citizen holding the nationality of the Member State of residence, irrespective of whether such an individual also holds the nationality of another Member State.

- The TCN family member of an EU citizen who holds, irrespective of the timing and mode of acquisition of these, the nationality of more than one Member State, and who has exercised his/her freedom of movement by residing either in a Member State other than that of which (s) he is a national, under Article 7(1) or Article 16(1) of the Directive, irrespective whether the EU citizen later acquired the nationality of this Member State, or, in a Member State of which he is a national other than the Member State in which he was born, while fulfilling the conditions as provided for in Article 7(1) of the Directive applied by analogy, shall have a derived right of residence under Article 21(1) TFEU, on conditions which must not be stricter than those provided for by Directive 2004/38 for the grant of such a right to a TCN who is a family member of a Union citizen who has exercised his right of freedom of movement by settling in a Member State other than the Member State of which he is a national.

This is a bit more technical, but would have solved multiple issues, which are unclear because of the specific wording of the Court.

In the following analysis, the multiple questions left open by Lounes will be considered.

\section{IV.1 Does Lounes Apply Only in the Member State of Naturalisation?- Geographical Scope}

If read strictly, one might consider that Mrs García Ormazábal retained her rights due to the fact that she never left the UK again after her naturalisation.

Such consideration must be denied. As stated above, the Court held that there does exist a link with EU law for dual EU citizens who reside in a Home MS, based on Freitag. The Court consequently ruled that a dual EU citizen, who has exercised the free movement rights in a Member State other than the Member State of origin - which one should read as Member State of birth continues to rely on the rights derived from Art. 21, para. 1, TFEU, "also against one of those two Member States". ${ }^{4}$

84 Ibid., para. 51. In French, the language of drafting at the Court it also contains the specific numericals: "compris à l'égard de l'un de ces deux États membres". 
One could take this literally, as meaning that the dual EU citizen can rely on it against one of the two, but not against both. Against the other Member State of nationality, rules like the ones set out in $O$ and $B$ would apply. This cannot, and may not, be argued.

Freitag concerned a dual EU citizen moving between the two Home MS, who wanted a civil status, the name, which had been changed in one Home MS during a period similar to Art. 6, para. 1, of the Directive, to be recognised in the other Home MS, where he resided. Consequently, it applies in both Home MS.

If it were to mean that it applied only in the Home MS of naturalisation, and only for as long as the naturalised dual EU citizen does not move away again, this would have as a consequence that once again moving to another Member State would become very unattractive, since afterwards, the less favourable case-law would apply. It would also mean that the naturalised dual EU citizen might have to prove when applying for a residence permit for the TCN spouse, that (s)he has not yet made use of the free movement rights by moving to another Member State since the naturalisation. It can be quite cumbersome, if not even impossible, to prove a negative.

Lounes consequently must apply both in the Home MS of origin and the Home MS of naturalisation. Thus, the case Lounes applies only to applications of family reunification in any Home MS. A dual EU citizen in an MS country has an MS/MS combination and consequently either the Zhu and Chen or the Micheletti constellation applies.

This, however, could also mean that the Home MS of origin would have to treat a dual EU citizen who naturalised in another Member State differently from someone who did not naturalise in the host Member State and then returns, since $O$ and $B$ would still be applicable to the latter.

This leads to an essential question: to whom exactly does Lounes apply?

\section{IV.2 To Whom Does Lounes Apply? - Individual Scope}

More specifically, the question is: does Lounes only apply to dual EU citizens, or also to any naturalised EU citizens who previously had the nationality of another Member State and subsequently lost this nationality? To get to the latter part, one must first consider what the consequences would be if Lounes were to apply only to dual EU citizens.

a) Does Lounes apply only to naturalised dual EU citizens? This question is going to be crucial.

According to Art. 5, para. 2, of the European Convention on Nationality $(\mathrm{ECN})$, to which many Member States are party, "[e]ach State Party shall be guided by the principle of non-discrimination between its nationals, whether they are nationals by birth or have acquired its nationality subsequently". 
According to the Explanatory Report to the Convention, "shall be guided by" indicates a declaration of intent and not a mandatory rule. The explanatory report further clarifies that it is aimed at "eliminating the discriminatory application of rules in matters of nationality between nationals at birth and other nationals, including naturalised persons". It then explicitly states that Art. 7 , para. 1, let. b), is an exemption from this rule, which concerns loss of nationality because of acquisition by fraudulent means. ${ }^{85}$ One should thus consider that only profound reasons could allow for a deviation from this general principle of non-discrimination based on the mode of acquisition.

If Lounes were to apply only to dual EU citizens who acquired the nationality of another Member State at a later point in life through naturalisation, it would put naturalised dual EU citizens in a better position than "birth" dual EU citizens, which is prohibited by Art. 5, para. 2, ECN.

This would be unfair also because a "birth" dual EU citizen cannot "upgrade" his nationality status.

Limiting the scope of Lounes to naturalised dual EU citizens does not seem to have been the intention of the Court, as it states in para. 54 that "denying [the dual EU citizen] that right would amount to treating him in the same way as a citizen of the host Member State who has never left that State [read Shirley McCarthy], disregarding the fact that the national concerned has exercised his freedom of movement by settling in the host Member State". Even though it might not be the Court's intention to limit the effects of Lounes to naturalised dual EU citizens, we should still have a look at all the consequences that different forms of limited interpretation of the judgment might have concerning naturalisation.

b) Does Lounes apply to a specific mode of nationality acquisition or does it require a certain genuine link with the nationalities? Mrs García Ormazábal was naturalised, which requires a certain period of residence and proof of integration. The Court emphasised in its judgment that she had sought to become more "deeply integrated" or "permanently integrated". The Court also stated that there is an "underlying logic of gradual integration that informs Article 21(1) TFEU". She therefore retained her rights as EU citizen, because she had integrated.

However, only the ordinary naturalisation requires integration, whereas other modes of acquisition do not necessarily, especially where nationality is acquired abroad iure sanguinis, but also for facilitated naturalisations or acquisition by option. 
The nationality codes of the Member States are very diverse, and in each and every single one of them there are modes of facilitated acquisition of nationality, which require a shorter period of residence, or even no residence. With this, I do not refer only to Investment Citizenship, but also to any form of facilitated naturalisation e.g. spouses of nationals, children born out of wedlock if they do not acquire the nationality automatically upon recognition, or persons where a family member in ascending line was a national. This is even required by Art. 6, para. 4, ECN.

Could a Member State now refuse to give effect to the MS rank nationality of a dual EU citizen in the Home MS, because it was acquired via a facilitated mode of acquisition instead of through the ordinary naturalisation? ${ }^{86}$

It definitely could not. This would be an additional condition for recognition of the nationality of another Member State, as prohibited by the Court in Micheletti.

Furthermore, when applying for naturalisation, a person does not really have a choice for one mode of acquisition or another. If (s)he fulfils the conditions of a facilitated naturalisation that mode is applied, even though the higher set of conditions for another mode of acquisition would also be fulfilled.

On top of this, it would be legally impossible for a person to "upgrade" the nationality acquired by one mode, to the same nationality acquired by another mode. This is because nationals have to be treated equally, irrespective of how they acquired the nationality from the Home MS. The Member State of nationality is therefore even prohibited from providing for such an "upgrade", as that would explicitly acknowledge a different rank in status based on the mode of acquisition of nationality.

One should also consider that the Court accepted only on one occasion that a nationality of a Member State would not be applied, because of the way in which it had been acquired. However, there it concerned the Home MS rank nationality acquired ex lege by marriage to a national, which would otherwise have resulted in a loss of rights derived from the MS rank nationality. ${ }^{87}$

Furthermore, there are modes of facilitated naturalisation that do not require any residence. Would Lounes not be applicable in such a case?

Imagine the following situations:

- what if, a person of Hungarian origin would naturalise in Hungary in accordance with Section 4, para. 3, of the Act on Hungarian Citizenship, which

86 A similar question was asked by Steve Peers in his comment on the judgment. See: Peers, S. (2017). Dual Citizens and EU Citizenship: Clarification from the ECJ. EU Law Analysis, available at eulawanalysis.blogspot.com.

87 This was the Airola case. Court of Justice, judgment of 20 February 1975, case 21/74, Airola v. Commission. 
does not require residence, but only knowledge of the language, while still residing in the other Member State of nationality? ${ }^{88}$

- what if, a child is born in a Member State of which it automatically acquires the nationality, and only at a later moment acquires the nationality of another Member State iure sanguinis, by registration, as that Member State has no automatic iure sanguinis abroad if only one parent is a national e.g. the situation of Slovenian nationality?

All these questions have the same answer.

Based on the principle of recognition of nationality and national jurisdiction concerning nationality, a Member State has to recognise the grant of nationality by another Member State and consequently that the person involved has become a dual EU citizen.

As was established in Lounes, what is important is that the person has had the mobility quality. If (s)he has never made use of the free movement rights, Shirley McCarthy applies.

Therefore, if at any moment before in life, a person has made use of free movement rights, he or she can derive rights from Art. 21, para. 1, TFEU on acquiring the nationality of the other Member State and becoming a "Home MS/ MS residence Home MS/Home MS". In the latter situation though, the person must be a returner; thus, it would be rather curious that the mobility quality would first be dormant upon return, and only the rights previously used would be retained, because of attachment to the Home MS rank. ${ }^{89}$ Conversely, without movement, but by acquiring the nationality of another Member State, the mobility quality would become reactivated for eternity, because of automatic attachment to the MS rank.

As will be explained, the Court must change its approach in $O$ and $B$, where it concerns the application of rights after return.

Lounes must, at the minimum, be applied to any dual EU citizen, irrespective of the mode of acquisition of the nationalities. It therefore not only applies to ordinary naturalisations, but also to any form of naturalisation, as well as to "birth" dual EU citizens who have the mobility quality.

88 Act LV of 1993 on Hungarian Citizenship of 15 June 1993 as amended by Act XLIV of 26 May 2010 (Hungary), 2010, Évi XLIV. törvény a magyar állampolgárságról szóló 1993. évi LV. törvény módosításáról.

89 Has made use of the free movement rights means once upon a time "MS movement .../ MS"; as the person resides at the time of acquisition of the other nationality in the Home MS, the person must have come back "Home MS movement MS/Home MS" and then consequently after acquisition of the other MS nationality become "Home MS/MS residence Home MS". 
c) Must the individual have retained the other Member State nationality? The condition of retention of the previous Member State nationality is where the main crux in this story is. The Court emphasises on multiple occasions in the judgment concerning Art. 21, para. 1, TFEU that Mrs García Ormazábal had retained her nationality of origin..$^{90}$ Considering how restrictively certain national courts and governments interpret CJEU judgments, this can lead to the conclusion that, if the EU citizen does not retain the other MS rank nationality when naturalising in the Member State of residence, the case is not applicable.

Many Member States have introduced rules with exceptions for retention of the original nationality upon naturalisation if the original nationality is of one Member State, and/or have created an exception to the automatic loss of their nationality upon acquisition of another nationality, if this is the nationality of another Member State.

A logical reaction of the Member States to Lounes would be that these rules would once again be abolished. For, if Mrs García Ormazábal had not retained her Spanish nationality, the mobility quality would not have been attached to her MS rank nationality, but to the Home MS rank nationality. Consequently, as was seen in $O$ and $B$, only the rights used before would have been retained, and the mobility quality for future use would have been lost, correct?

According to the Court's judgments in Micheletti and in Rottmann, Member States must, "when exercising their powers in the sphere of nationality, have due regard to European Union law". ${ }^{91}$ The judgment of Rottmann has been discussed a lot in the literature and was considered by some to be surprising, despite the fact that this exact line of reasoning had already been put forward as far back as the 198 os and gos. ${ }^{92}$ One could thus wonder whether a duty to renounce the other Member State nationality upon naturalisation, or the automatic loss of the original Member State nationality, would be in accordance with EU law.

$90 \quad$ Lounes, cit., paras. $49,54,6$ o, and 62.

91 Court of Justice, judgment of 2 March 2010, case C-135/o8, Rottmann, para. 45.

92 Greenwood, C. (1987). Nationality and the Limits of the Free Movement of Persons in Community Law. Yearbook of European Law 7 (1), pp. 185-210; Evans, A.C. (1982). Nationality Law and the Free Movement of Persons in the EEc. Yearbook of European Law 2 (1), pp. 173-189; Hartley, T.C. (1978). EEC Immigration Law. Amsterdam: North Holland Publishing Co., p. 78. According to Síofra O'Leary these authors argued that “[s]ince nationality is a means to define the personal scope of free movement and since it is also a means chosen by the Community, they argue that it is also a question for Community law, or at least on which Member States cannot unilaterally dispose of without reference to Community law". This is exactly what has happened in later case-law. O'Leary, S. (1992). Nationality Law and Community Citizenship: A Tale of Two Uneasy Bedfellows. Yearbook of European Law 12 (1), pp. 353-384. 
d) Presuming that Lounes only applies to dual EU citizens: automatic loss upon acquisition of the nationality of another Member State. Automatic loss or withdrawal of one nationality upon acquisition of another used to be quite common practice back when dual nationality was still considered a bad thing. However, many Member States abandoned that practice, ${ }^{93}$ although in some exceptional cases they then (re)introduced it. ${ }^{94}$

Art. 7, para. 1, let. a), ECN provides that such a mode of loss is permitted. However, if Lounes applies only to dual EU citizens, automatic loss of the original Member State nationality upon acquisition of another Member State's nationality would mean that EU citizens who "have acquired rights under [Art. 21, para. 1, TFEU] as a result of having exercised their freedom of movement, must forgo those rights [...] because they have sought, by becoming naturalised in [the other] Member State, to become more deeply integrated in the society of that [other] State". 95

Therefore, one should consider the first case that truly concerned loss of EU citizenship based on loss of the nationality of a Member State: Rottmann. ${ }^{96}$

In that case, the Court decided that:

[t]he provis[ion] that due regard must be had to European Union law does not compromise the principle of international law previously

93 Globalcit Database ground of loss L5. It was abandoned by Denmark in 2015 (law no. 1496 of 23 December 2014 (Denmark), Lov om cendring af lov om dansk indfødsret (Accept af dobbelt statsborgerskab og betaling af gebyr i sager om dansk indfødsret), in force since 1 September 2015). It still exists in Austria (Art. 27); Estonia (Art. 29); Ireland, but only for naturalised nationals who subsequently acquire another nationality (Art. 19, para. 1, let. e)); Germany, but is not applicable when acquiring the nationality of another Member State (Art. 17, para. 1, sub-para. 2, and Art. 25. The exception is mentioned in Art. 25, para. 1); Latvia, but provides that when one acquires the nationality of i.a. an EU Member State one retains Latvian nationality (Art. 23, para. 2, and Art. 24, para. 1, sub-para. 1. The exception for the nationality of another EU Member State is provided in Art. 9, para. 1, sub-para. 1); Lithuania (Art. 24, para. 2, and Art. 26); the Netherlands (Art. 15, para. 1, let. a), and Art. 16, para. 1, let. c) and e)); Slovakia (Art. 9, para. 1, let. b)); Spain, loss happens after three years of acquisition, but one can make a declaration within this period to retain the Spanish nationality (Art. 24, para. 1).

94 E.g. Slovakia in 2010 in response to the Hungarian changes on the grant of its nationality. Act no. 40/1993 on Citizenship of the Slovak Republic of 19 January 1993 as amended by Act no. 250/2010 of 26 May 2010 (Slovakia), Zákon, ktorým sa mení a doplña zákon Národnej rady Slovenskej republiky č. 40/1993 Z. z. o štátnom občianstve Slovenskej republiky $v$ znení neskoršich predpisov. Zbierka zákonov Slovenskej republiky č. 250/2010.

95 With slight alterations, Lounes, cit., para. $5^{8}$.

96 It is generally accepted that Kaur (Court of Justice, judgment of 20 February 2001, case C192/99, Kaur) did not concern a loss of EU citizenship because she never had it. Therefore, Rottmann is the only case up until Tjebbes. 
recognised by the Court, [...] that the Member States have the power to lay down the conditions for the acquisition and loss of nationality, but rather enshrines the principle that, in respect of citizens of the Union, the exercise of that power, in so far as it affects the rights conferred and protected by the legal order of the Union, as is in particular the case of a decision withdrawing naturalisation such as that at issue in the main proceedings, is amenable to judicial review carried out in the light of European Union law. ${ }^{97}$

The Court further stated in Rottmann "that the principles stemming from this judgment with regard to the powers of the Member States in the sphere of nationality, and also their duty to exercise those powers having due regard to European Union law, apply both to the Member State of naturalisation and to the Member State of the original nationality". 98

This means that judicial review by the Member State of origin would also have to be applied if it wants to take away rights derived from EU law. A similar issue was under consideration in Tjebbes. ${ }^{99}$ That case concerns the ground for automatic loss of the Dutch nationality for dual nationals while residing outside of the EU and without applying for a new Dutch identity document within ten years. Next to Dutch nationality, several of the applicants also have Swiss citizenship and reside in Switzerland. If the Swiss courts were to apply Lounes, which conflicts with their own recent case-law, a situation as in Tjebbes would mean that they had EU citizen rights, in Switzerland - irrespective of the fact that these were denied by the Swiss authorities - and would have lost them, due to the automatic loss resulting from living outside the territories of the EU. ${ }^{100}$ The Court, however, in its judgment did not take this into consideration and even stated that all applicants had never made use of the

$97 \quad$ Rottmann, cit., para. 48.

$98 \quad$ Ibid., para. 62.

99 Court of Justice, judgment of 12 March 2019, case C-221/17, Tjebbes.

100 Up until 2016 dual EU-Swiss (EU-CH) citizens were considered to fall within the ambit of the bilateral treaties even when they had not made use of the free movement rights. Swiss Federal Supreme Court, judgment of 28 January 2016, C2_296/2015. See also Epiney, A., and Nüesch, D. (2016). Zur schweizerischen Rechtsprechung zum Personenfreizügigkeitsabkommen. In: Achermann, Amarelle, Caroni, Epiney, Künzli, and Uebersax, eds., Jahrbuch für Migrationsrecht 2015/2016. Bern: Stämpfli Verlag, p. 310. This changed when the courts decided to apply $O$ and $B, S$ and $G$ and Shirley McCarthy to similar situations in Switzerland, while applying it to a dual EU-CH citizen who had made use of the free movement rights before. Swiss Federal Administrative Court, judgment of 10 February 2016, C-3189/2015; Swiss Federal Supreme Court, judgment of 20 January 2017, C2_284/2016. 
free movement rights and, therefore, excluded Art. 21 TFEU from the scope of the case. ${ }^{101}$

In Rottmann, the Court stated that "[h]aving regard to the importance which primary law attaches to the status of citizen of the Union, when examining a decision withdrawing naturalisation [read 'the nationality'] it is necessary, therefore, to take into account the consequences that the decision entails for the person concerned and, if relevant, for the members of his family with regard to the loss of the rights enjoyed by every citizen of the Union".102

Considering the fact that in Lounes, the Court accepted that the naturalised dual EU citizen continues to have family reunification rights derived from Art. 21, para. 1, TFEU, this has to include future family members. It is unfortunate, that the Court did not take the issue of Art. 21 TFEU into consideration in Tjebbes. While the Court decided that the nationality of a Member State may be lost while residing in a Third Country as long as certain conditions are fulfilled, it should have strongly distinguished this from the same person residing in a Member State or a TC+. By the exclusion of Art. 21 TFEU from the scope of the judgment, one might derive that different rules would have been applicable if such a loss by residence abroad could occur while residing in another Member State. The Court, however, should have replaced the application of Art. 21 TFEU, with the application of the Bilateral Treaties with Switzerland which do grant free movement rights.

If an automatic loss in a Member State would be permitted, it would also mean that persons from Member States which provide for automatic loss upon acquisition of another nationality would be less inclined to become "fully integrated" in another Member State, because they would lose their original Member State nationality and consequently any rights they derive from having an MS rank nationality. These EU citizens would be thus at a disadvantage compared to nationals from Member States that allow the retention of their nationality.

Although an instance of reverse discrimination, here the reason for the loss would be because the persons had made use of the free movement rights.

e) Presuming that Lounes only applies to dual EU citizens: duty to renounces the other Member State nationality. This question is maybe more straightforward than the previous one.

If Lounes only applies to dual EU citizens, then such a duty to renounce the other Member State nationality would mean that the EU citizens would have to forgo his acquired rights in order to naturalise in another Member State.

\footnotetext{
101 Tjebbes, cit., para. 28.

102 Rottmann, cit., para. 56.
} 
Consequently, such a duty to renounce the other Member State's nationality upon naturalisation may not be required.

f) Presuming that Lounes only applies to dual EU citizens: conclusion. If Lounes only applies to dual EU citizens, it must have consequences for national rules concerning loss and acquisition of nationality. Specifically, it must have consequences for the rules on automatic loss of nationality upon acquisition of another nationality, and for the rules on duty to renounce the previous nationality upon acquisition.

One should take into account that these rules should not only apply where the previous nationality is the nationality of a Member State, but also where the previous nationality is of a TC+. It should furthermore apply to candidate states - which are already mostly TC+ - and also to any possible future candidate states. If not to the latter, these candidate states should, upon becoming Member States, create an option possibility for any former nationals who acquired the nationality of a Member State and consequently lost the former candidate state's nationality. The reacquisition of the nationality would not result in a loss of the Member State's nationality, since it would have been an acquisition of the nationality of another Member State.

g) Presuming that Lounes applies to any EU citizen who had the nationality of one Member State when acquiring the nationality of another Member State. Let us now look at the other side, and presume that Lounes applies to any EU citizen who had the nationality of one Member State when acquiring the nationality of another Member State, thus including individuals who had lost their original Member State nationality due to naturalisation. This yields an entirely different set of results and issues.

If Lounes were to apply only to naturalised EU citizens, it would mean that Lounes would clearly give an advantage to naturalised EU citizens, compared to those who did not acquire the nationality by naturalisation, but by another mode of acquisition. This is incompatible with Art. 5, para. 2, ECN.

Next to the legal problem, there are also practical implications. Either a Member State would have to check for every returner in turn whether the individual had acquired the nationality by naturalisation and what the previous nationality was, or the individual would have to prove this. The first option means that the Member State would actively have to make a distinction in its law and practice on registration between certain groups of its own nationals.

As this is not allowed, the Court would have to change its approach concerning $O$ and $B$ and also give the same rights as dual EU citizens in the Home MS to persons who only had one nationality at birth and subsequently never acquired another one. The Court recently decided on three cases concerning the right to return. The Coman case concerns the right to return as regards 
same-sex marriages and the Banger case concerns the right to return as regards non-marital relationships. ${ }^{103}$ In these cases, the Court could have considered the issue. It has not been addressed specifically in either case though, and the Court did not deal with it. ${ }^{104}$

However, in Altiner and Ravn, it concerns exactly the question of whether the mobility quality stays active after return. ${ }^{105}$ The case concerned a Danish national married to a TCN, who resided together in Sweden. They returned to Denmark and were covered by the right to return. After a while, they requested family reunification with the son of the TCN spouse from a previous marriage, who was also covered as a privileged family member under Art. 2, para. 2, let. c), of the Directive. The son did, however, not reside with them in Sweden and consequently would be excluded from the scope set by $O$ and $B$. This would have been the perfect opportunity for the Court to overrule or enlighten its judgment in $O$ and $B .{ }^{106}$

That Lounes would apply to any naturalised EU citizen who previously held another Member State's nationality has, however, also other consequences. It means that the Court will have to rethink its case-law in other fields as well, like the Baldinger case. ${ }^{107}$ This case concerned war victim benefits that were granted to Austrian nationals. Mr Baldinger was an Austrian national in the

103 Court of Justice, judgment of 5 June 2018, case C-673/16, Coman and others; Court of Justice, judgment of 12 July2018, case C-89/17, Banger.

104 In Coman the Court did refer multiple times to Lounes concerning the right to return in general. From this one can deduct that Lounes also applies in the Member State of birth and not only in the Member State of naturalisation. However, when it concerned the particular situation, the Court only referred to $O$ and $B$. This distinction is probably due to fact that it concerned an accompanying family member and not a joining family member. Coman and others, cit., para. 24 compared to paras. 18, 20, 22, 23, 25 .

105 Court of Justice, judgment of 27 June 2018, case C-230/17, Altiner and Ravn. It concerns a Danish national who had resided in Sweden with her Turkish spouse. They return to Denmark and later request family reunification with the son from a previous marriage of the Turkish spouse, which was denied by the Danish authorities based on $O$ and $B$.

106 Altiner and Ravn was decided without an Opinion of AG Wahl. This means that AG Wahl probably considered that the "return" case-law, meaning $O$ and $B$, is clear and should be applied directly to this case. This would mean that no "new" family reunification would be granted after return to Denmark. The Court followed this approach. Consequently, this means that there is a different line of case-law applicable to dual EU citizens and "single" EU citizens. This must have as a consequence that Member States are no longer permitted to provide for automatic loss of their nationality upon acquisition of another Member State's or TC+'s nationality, nor may the condition for acquisition be made that the previous nationality is renounced, where this nationality is of a Member State or TC+, as was explained supra.

107 Court of Justice, judgment of 16 September 2004, case C-386/o2, Baldinger. I would like to thank Dominik Düsterhaus for drawing my attention to this case. 
Second World War and was taken prisoner of war. Later, he moved to Sweden and naturalised. As Austria has a strict single nationality policy, Mr Baldinger subsequently automatically lost Austrian nationality. Because of this loss of nationality, Mr Baldinger was considered not to fall within the scope of Austrian war victim benefits. The Court accepted this. In a subsequent case, TasHagen, it also concerned the refusal of war victim benefits, but in this case it was based on residence abroad while the applicant had retained the nationality of the country granting the benefit - the Netherlands - while residing in Spain. ${ }^{108}$ In that case, the Court considered that the condition of residence in the Member State granting the benefit was incompatible with the right to free movement. 109

Therefore, using the free movement rights may not impede continuous access to certain benefits from the Home Member State while retaining the nationality; however, losing the nationality by acquiring the nationality of another Member State was considered an acceptable reason to discontinue the grant of these benefits. With Lounes, this might become a dubious stance of the Court.

h) Conclusion: Lounes should apply not only to dual EU citizens, but to all EU citizens. If one compares the two consequence analyses of whether Lounes applies to only dual EU citizens or to any EU citizen who naturalised and previously already had the nationality of a Member State, it becomes clear that both are quite burdensome.

If it applies only to dual EU citizens it must have consequences on the freedom of Member States to decide on grounds of loss of their nationality and on conditions of renunciation of the previous nationality. On the other hand, if it applies to any EU citizen who has moved, because it cannot apply only to naturalised EU citizens as was already explained above, this means that not only the "return" case-law has to be revisited, but any case-law where it concerned a person who had lost the nationality of a Member State upon naturalisation in another Member State.

\section{IV.3 Emphasis on Having the Mobility Quality}

The Court in Lounes, just like in Shirley McCarthy, emphasised the importance for dual EU citizens of having made use of the free movement rights, consequently of having the mobility quality. In certain constellations, this might give rise to some issues.

108 Court of Justice, judgment of 26 October 2006, case C-192/o5, Tas-Hagen.

109 Cousins, M. (2007). Citizenship, Residence and Social Security. European Law Review 32, pp. 386-395, 393 . 
a) Catherine Zhu naturalises and Shirley McCarthy renounces. What if Catherine Zhu would naturalise in the UK while retaining her Irish nationality? The child at first would be using the free movement rights. However, afterwards she would be in the same situation as Shirley McCarthy, since she would live in the Home MS in which she was born and has always resided.

As the mobility quality had been active before acquisition of the Home MS rank nationality, the mobility quality would be attached to the MS rank nationality and consequently, a lifetime of rights derived from Art. 21, para. 1, TFEU would be granted.

This also means that it would theoretically be possible to maximize the applicability of EU law by influencing the order of acquisition of nationality, each resulting in another legal basis for residence. ${ }^{110}$ It also means that a child who is born and resides in a Member State of which it does not have the nationality, but acquires the nationality of two other Member States at birth iure sanguinis, automatically is covered by Art. 21, para. 1, TFEU for its entire life. ${ }^{111}$

The only way to prevent this automatic coverage by Art. 21, para. 1, TFEU for a child who only has the nationality of another Member State at birth, but not the one of residence, would - rather ironically - be that the Member State of residence grants its nationality to such a child at birth iure soli. Only after the child would make use of the free movement rights by moving somewhere else would it gain lifetime coverage of Art. 21, para. 1, TFEU.

It would of course be peculiar to grant nationality in order to prevent a child from deriving rights from EU law. For, what the Member State in essence wants is to prevent family reunification with TCN spouses based on EU law. One might consider it a bit premature and excessive to grant nationality to a child at birth in order to prevent it from having "family reunification with the spouse". Especially since the child who has reached the age of majority when it is allowed to marry might easily circumvent the rules by moving to another Member State and by later returning to the Member State of birth. Member States would do better, to simply accept the fact that, if a child like Catherine Zhu naturalises in the Member State of birth, it has a lifetime coverage of Art. 21, para. 1, TFEU.

Purely theoretically, a Member State could also in such a case, retroactively to the time of birth, grant its nationality to the child, when it requests for family reunification. The subsequent time of residence in between the time of birth and the time of the retroactive grant of nationality would have to be

\footnotetext{
110 This influencing can only be done where the nationality of a Member State is only acquired upon registration with the authorities of that Member State.

111 Thus "MS/MS residence MS".
} 
considered as if it had been spent as a national and not based on the Directive. However, this would be an absolute abuse of the grant of nationality by the Member State in order to prevent a person from exercising his rights derived from Art. 21, para. 1, TFEU.

Another issue is the question what if Shirley McCarthy had renounced her British Citizenship based on Section 12 of the 1981 British Nationality Act? ${ }^{112}$

In that case, she would have been in a similar position as Catherine Zhu, and the Directive would have applied, had she been a worker. ${ }^{113}$ This renouncement would technically speaking be an abus de droit. The rules on abus de droit state that an action by an EU citizen, which is entirely artificial and only done to come within the ambit of EU law is prohibited. But one can hardly argue that renouncing a Member State's nationality should be required to fall within the ambit of EU law. This would be paradoxical.

What makes this similar to Lounes is that it should also be considered whether Mrs McCarthy could afterwards have re-acquired or resumed her British citizenship based on Section 13, para. 3, of the British Nationality Act, or if she could have re-naturalised. ${ }^{114}$ This Section requires approval from the Secretary of State, who might refuse to grant resumption because the renouncement was only made in order to fall within the ambit of EU law, which might be considered abusive.

However, refusing to grant nationality on the grounds that the person wanted to fall within the ambit of EU law and make use of the free movement rights would again be a restriction of Art. 21 TFEU.

b) Other methods that the Court could have used in Lounes. The Court could have also handled Lounes in other ways, and might still use these to overcome the $O$ and $B$ restrictions.

Over the years, the Court seems to have only concentrated on Arts 18 and 21 TFEU, and has put its own case-law related to the other free movement rights on a back shelf. To refer again to the words of Szpunar and Blas López - Union citizenship has become a victim of its own success.

When a case concerning dual EU citizens is pending, the Court should remember that the Directive has five legal bases:

112 Maas, W. (2014), The Origins, Evolution, and Political Objectives of EU Citizenship. German Law Journal 15 (5), pp. 797-820, 816.

113 The formula would be "MS residence Home MS/MS". As renouncement would lead to the fact that she would no longer be a dual EU citizen, only a single MS is entered.

114 Resumption based on Section 13, para. 1, is not possible as this requires that the renouncement was made in order to acquire or retain another nationality based on Section 13, para. 1, let. b). Section 13, para. 3, allows for the resumption of British citizenship on the discretion of the Secretary of State. 
a) Art. 12 EC (now Art. 18 TFEU) - principle of non-discrimination based on nationality;

b) Art. $18 \mathrm{EC}$ (now Art. 21 TFEU) - EU citizenship;

c) Art. $40 \mathrm{EC}$ (now Art. $46 \mathrm{TFEU}$ ) - Free movement of workers;

d) Art. 44 EC (now Art. 50 T FEU ) - Free movement of establishment;

e) Art. $5^{2}$ EC (now Art. 59 TFEU ) - Free movement of services.

It is curious that where a Carpenter ${ }^{115}$ and $S$ and $G^{116}$ constellation exists for a person who only has the nationality of the Home MS, Art. 45 TFEU is applicable, and therefore the Directive is also applicable by analogy. If the person is a dual EU citizen, the Court only considers Art. $21 \mathrm{TFEU}$, and consequently is mostly more restrictive on any application of the Directive.

Another option of what the Court could have done is applying Micheletti more strictly. Before the Shirley McCarthy case, this was also considered an acte clair by the national courts, with the exception apparently of the British courts. The requirement of not-having-the-nationality-of-the-Member-Stateof-residence was considered an additional requirement to the "recognition" of the nationality of another Member State. Some courts even applied this principle to persons who naturalised at a moment when their State of nationality had not yet acceded to the EU.117 They considered that from the moment that State had joined, the person, although already a national of the resident Member State, was exercising the free movement rights. ${ }^{118}$

One could argue that the wording of Art. 3, para. 1, of the Directive is substantially different from the wording of Art. 1 of its predecessor Regulation $1612 / 68,{ }^{119}$ and that therefore its scope is also different. However, in

115 Carpenter, cit.

116 Court of Justice, judgment of 12 March 2014, case C-457/12, S and G.

117 Dutch Council of State, judgment of 25 March 2013, BZ7520.

118 Ibid., para. 5.2: "Het standpunt van de minister dat de referente is genaturaliseerd voordat Bulgarije tot de Europese Unie toetrad en zij om die reden geen rechten kan ontlenen aan haar Bulgaarse nationaliteit, veronderstelt dat het bezitten van de Nederlandse nationaliteit kan afdoen aan de rechten die referente aan haar hoedanigheid van burger van een andere lidstaat aan het Unierecht ontleent. Voor die veronderstelling bestaat, gelet op jurisprudentie van het Hof, geen grond". Similar also Dutch Council of State, judgment of 28 January 2013, BZo412, para. 2.2. See for the case-law up to 2013: van Rosmalen, A. (2013). Conditional Citizenship of the Union? Family Migration for EU citizens and the Outdated Notion of "Internal Affairs". Hanneke Steenbergen Scriptieprijs, available at steenbergenscriptieprijs.nl.

119 Art. 1 of Regulation (EEC) 1612/68 of the Council of 15 October 1968 on freedom of movement for workers within the Community: "1. Any national of a Member State, shall, irrespective of his place of residence, have the right to take up an activity as an employed person, and to pursue such activity, within the territory of another Member State in accordance with the provisions laid down by law, regulation or administrative action 
Scholz, ${ }^{120}$ which concerned a dual German-Italian citizen in Italy, the Court stated that:

It should be borne in mind, first of all that Article 7 of the Treaty [now Art. 18 TFEU], which prohibits any discrimination on grounds of nationality, does not apply independently where the Treaty lays down, as it does in Article 48(2) [now Art. $45 \mathrm{TFEU}$ ] in relation to the free movement of workers, a specific prohibition of discrimination. [...] In addition, Articles 1 and 3 of Regulation No 1612/68 merely clarify and give effect to the rights already conferred by Article 48 of the Treaty. Accordingly, that provision alone is relevant to this case. ${ }^{121}$

This means that under Art. 45 TFEU, a dual EU citizen can invoke the Directive by analogy against the Home MS, while under Art. 21 TFEU this might not be possible, even though this article incorporates the rights under Art. 45 TFEU.

In that case, the Court also held that "[a]ny Community national who, irrespective of his place of residence and his nationality, has exercised the right to freedom of movement for workers and who has been employed in another Member State, falls within the scope of the aforesaid provision".122

The application of Art. 45 TFEU would be a system of creating a "mobility quality". If a dual EU citizen is a worker, self-employed or has sufficient means, (s)he gains access to the quality. If (s)he becomes unemployed, loses the business or resources, this mobility quality continues to have effect for as long as the Directive provides under Art. 9, but is lost afterwards, except if more favourable conditions are applicable.

However, the option taken by the Court is the most favourable by a simple reference to the name case-law, which it did by referring to this sentence from Freitag which is similar to Scholz, but based on Art. 21 TFEU: "[a]ccording to settled case-law, a link with EU law exists in regard to nationals of one Member State lawfully resident in the territory of another Member State [...]. That is the case as regards the applicant in the main proceedings, who is a Romanian national and is resident in the territory of the Federal Republic of Germany, of which he is also a national". ${ }^{123}$ It should be remembered, though, that for

governing the employment of nationals of that State. 2. He shall, in particular, have the right to take up available employment in the territory of another Member State with the same priority as nationals of that State".

120 Court of Justice, judgment of 23 February 1994, case C-419/92, Scholz.

121 Ibid., para. 6.

122 Ibid., para. 9.

123 Freitag, cit., para. 34. 
the name case-law, actual movement, and therefore the mobility quality, is not required.

\section{v Conclusion - a Choice: Nationality Competence or Abandonment of Reverse Discrimination}

In Lounes, the Court decided in favour of European integration, by making it clear that integration - and therefore naturalisation - does not affect the future applicability by analogy of Directive 2004/38/EC.

It must be reiterated that, had the Court decided against European integration instead, it would have been remarkable that a UK-EU dual citizen would have had more rights in the other Member State of nationality after Brexit, as a TC+, than before.

With Lounes it is now clear that the mobility quality always gets attached to a present MS rank nationality even when a Home MS rank nationality is present. In the absence of an MS rank nationality though, it gets attached to the Home MS rank nationality which only allows rights to be retained which were previously used while it was an MS rank. This differentiation between the MS and Home MS ranks cannot stand in the long run. Only when they are treated equally can EU citizenship become a reality.

Even though the ruling in Lounes is favourable, it has its flaws, which will manifest themselves sooner or later. These flaws are created by the fact that the Court did not make clear how $O$ and $B$ and Lounes are interlinked, except where it concerned the documentation required. This will create an imbalance between the rights of dual EU citizens and of "single" EU citizen returners. Furthermore, is it detrimental for EU citizens with certain nationalities who would lose the original Member State nationality compared to those who can retain it.

The Court has now an uncomfortable choice. If the Court considers that Lounes only applies to dual EU citizens, this means that it has to limit the competence of the Member State in the field of nationality law. If it does not want to do so, it has no choice but to revoke the previous family life requirement for returners established in $O$ and $B$. This would mean though that any EU citizen who has ever made use of the free movement rights would be covered by the Directive by analogy for a lifetime, for example after doing an Erasmus.

The earliest option for the Court to make this choice was Coman, Banger or Altiner and Ravn. Especially in Altiner and Ravn the Court seems to have made the choice that Lounes is not applicable to "single" EU citizens. The Court did relax the residence requirement to some extent by replacing the Art. 7, para. 2, 
residence requirement with a previously in the host Member State established and uninterrupted family life requirement. ${ }^{124}$ In Tjebbes the Court should have made a distinction between those applicants living in a third country and those living in a privileged third country. Since it has not done so, this will have consequences for future relations with the UK after Brexit.

The Court has to keep in mind that, based on the ECN, naturalised persons and persons who had the nationality at birth have to be treated equally and that the same principle applies to dual EU citizens.

To the question of how the Court should take dual EU citizens into account, I would like to state the following: the Court (and the EU legislator) should refrain from making not-having the nationality of the Member State of Residence a condition for the applicability of secondary legislation. If it does, under no circumstances may it make - like it did in $O$ and $B$ - previous applicability of that secondary legislation conditional on future application in a Member State of nationality. Such a double condition is only detrimental for dual EU citizens.

The Court should also, in cases of recognition of names, be very careful where it allows for a restriction based on constitutional values, because this might lead to a conflict of national Constitutions. ${ }^{125}$ It should especially be

124 The Court held in Altiner and Ravn that the TCN family member can also join the EU citizen at a later in the Home Member State (Altiner and Ravn, cit., paras. 29 and 31). The TCN family member would no longer have a derived right based on the Directive in the host Member State when the EU citizen leaves (Court of Justice, judgment of 16 July 2015, C-218/14, Singh, para. 58; Court of Justice, judgment of 30 June 2016, case C-115/15, $N A$, paras 34 and 35). This means that a previous Art. 7, para. 2, residence right cannot be required when the TCN family member joins the EU citizen in the Home Member State. Consequently, if the TCN family member stayed in the host Member State after the EU citizen left, this also means that (s)he must have had an independent residence right there. In certain circumstances this independent residence right can be indirectly derived from the previous worker status of the EU citizen family member in the host Member State, e.g. the continued residence status to continue education. Court of Justice, judgment of 17 September 2002, case C-413/99, Baumbast; Court of Justice, judgment of 23 February 2010, case C-310/o8, Ibrahim; NA, cit., paras. $5^{8}$ and 59. See Hoogenboom, A. (2017). Balancing Student Mobility Rights and National Higher Education: Autonomy in the European Union. Leiden, Boston: Nijhoff, pp. 127-128.

125 For example: what if Ilonka Sayn-Wittgenstein had next to the Austrian nationality also the nationality of Germany? The prohibition and the "grant" of the title of nobility would have been based on each Constitution. Unfortunately, both the Regional Administrative Courts of Salzburg and of Oberösterreich did not request a preliminary ruling when they were confronted with exactly this issue and decided that the Austrian Constitution applies. Regional Administrative Court of Salzburg, judgment of 25 January 2017, 40510/200/1/4-2017; Regional Administrative Court of Salzburg, judgment of 28 June 2017, 405-10/265/1/7-2017; Regional Administrative Court of Oberösterreich, judgment of 4 December 2017, LVwG-750471/3/BP/SA. 
careful where it is aware that there is a third party who is a dual EU citizen and would be directly affected by the case. For, did the Court ever consider in, for example, Runevič-Vardyn, ${ }^{126}$ what would happen to the son? ${ }^{127}$

It is regrettable that this son was not also an applicant in this case, for, would the Lithuanian authorities have issued a document for the child with his father's surname in its original form? No, they would not have. In fact, they refused to do so! In April 2016, the District Court of Vilnius ruled in a case where the authorities refused to register the name of a dual Lithuanian-Polish national who was born in Belgium, whose father is Polish and mother is Lithuanian, with the name Wardyn. ${ }^{128}$ The District Court decided that the name had to be entered with the "W" and thus the Polish spelling was to be used. Additional five years of litigation could have been saved if the Court had taken the effects of its judgment on this child into consideration. ${ }^{29}$

Dual EU citizenship is a symptom of European integration. European integration has led to EU citizens moving to other Member States and meeting and falling in love with nationals from these Member States. This, in combination with gender equality in nationality transmission, and acceptance of retention of other Member State's nationalities, leads to the logical consequence of an increasing number of dual and multi EU citizens. More and more cases on the free movement and dual citizenship will arise, because of a simple reason: we are nearing the final stages of full European integration. ${ }^{130}$

126 Runevič-Vardyn, cit.

127 In the Opinion of AG Szpunar in Sean Ambrose McCarthy he makes a similar example, but states that the person only has Lithuanian nationality and consequently not the Polish nationality (Opinion of AG Szpunar Sean Ambrose McCarthy, cit., para. 67). This is not entirely correct. It is true that Art. 3, para. 4, of the Lithuanian nationality code prohibits in general dual nationality. Exceptions to this are listed in Art. 7, one of them being that the other nationality was also acquired at birth and the person has not yet reached the age of 21. Upon reaching the age of 21 Lithuanian citizenship is lost by such persons if they have not renounced the other citizenship until that moment in accordance with Art. 24, para. 8. Another way to have dual citizenship in accordance with Art. 7, para. 5, is when the other nationality was acquired ex lege upon marriage.

128 Vilnius District Court, judgment of 12 April 2016, 2-01-3-11866-2010-1. Original decision available at: www.e-tar.lt; English translation of this decision (without name redaction) is available at: en.efhr.eu.

129 It is especially strange that the Court did not take this child into consideration as its existence and dual citizenship is mentioned in the judgment, Runevič-Vardyn, cit., para. 54.

130 E.g. Tjebbes and others, cit., concerning loss of a Member State's nationality of a dual national while living abroad. 
David A.J,G, de Groot - 9789004433076 Downloaded from Brill.come4/26/2023 03:26:21PM via free access 